\title{
An update on the fish composition (Teleostei) of the coastal lagoons of the Restinga de Jurubatiba National Park and the Imboassica Lagoon, northern Rio de Janeiro State
}

Uma atualização sobre a composição de peixes (Teleostei) das lagoas costeiras do Parque Nacional da Restinga de Jurubatiba e da lagoa de Imboassica, norte do Estado do Rio de Janeiro

Fabio Di Dario ${ }^{1}$, Ana Cristina Petry ${ }^{1}$, Matheus Maia de Souza Pereira ${ }^{1}$,

Michael Maia Mincarone ${ }^{1}$, Lorena Soares Agostinho' ${ }^{1}$, Ellen Martins Camara², Érica Pellegrini Caramaschi ${ }^{2}$ and Marcelo Ribeiro de Britto ${ }^{3}$

${ }^{1}$ Núcleo em Ecologia e Desenvolvimento Socioambiental de Macaé - NUPEM, Universidade Federal do Rio de Janeiro - UFRJ, CP 119331, CEP 27910-970, Macaé, RJ, Brazil e-mail: didario@macae.ufrj.br; ac_petry@yahoo.com.br; mathmsp@ig.com.br; mincarone@macae.ufrj.br; loh_ro@hotmail.com

${ }^{2}$ Departamento de Ecologia, Instituto de Biologia, Universidade Federal do Rio de Janeiro - UFRJ, Av. Carlos Chagas Filho, 373, CCS, Bloco A, Ilha do Fundão, CEP 21941-902, Rio de Janeiro, RJ, Brazil e-mail: camara.ellenm@gmail.com; erica.caramaschi@gmail.com

${ }^{3}$ Setor de Ictiologia, Departamento de Vertebrados, Museu Nacional, Universidade Federal do Rio de Janeiro - UFRJ, Quinta da Boa Vista, s/n, São Cristóvão, CEP 20940-040, Rio de Janeiro, RJ, Brazil e-mail: mrbritto2002@yahoo.com.br

\begin{abstract}
Aim: We present an update on the composition of the fish species of the Restinga de Jurubatiba National Park and the Imboassica Lagoon, in the northern portion of Rio de Janeiro State, based on collecting efforts of almost two decades, historical museum records, and a review of the literature. Methods: Specimens were collected using a variety of techniques, mostly between 1994 and 2012, and were fixed with the use of a $10 \%$ solution of formalin and subsequently stored in $70 \%$ alcohol solution. All specimens examined are deposited in the fish collections of the Núcleo em Ecologia e Desenvolvimento Socioambiental de Macaé, Universidade Federal do Rio de Janeiro (NPM), and Museu Nacional, Universidade Federal do Rio de Janeiro (MNRJ). Continental (freshwater) fishes and some marine or estuarine species frequently collected were regarded as Resident, whereas marine species collected only sporadically were regarded as Occasional. Possible associations between the orientation of the lagoons and the composition of Resident fishes were explored through a Correspondence Analysis (CA). Results: A total of 100 species, belonging to 19 orders and 41 families of the Teleostei were recorded. When both Resident and Occasional species are considered, families Carangidae and Engraulidae, with nine and eight species respectively, are the most representative. When only Resident species are considered, the Gerreidae and Gobiidae, both with seven species, are the most representative families. The Imboassica Lagoon, with 76 species, has the highest species richness among lagoons included in this study. A total of 81 species were recorded in the Restinga de Jurubatiba National Park, a number two times higher than reported on previous studies. An identification key, including 57 Resident species, is also presented. Conclusions: Parallel lagoons were characterized by a small group of continental species presumably of marine ancestry (Secondary Division), while marine species were more representative in Orthogonal lagoons. The higher frequency of marine species in Orthogonal lagoons is possibly associated with sandbar openings. Temporary and sporadic connections between Parallel lagoons during periods of higher rainfall may promote a higher similarity in terms of species composition.
\end{abstract}

Keywords: diversity, coastal environments, PELD, introduced species, identification key. 
Resumo: Objetivo: Apresentamos uma atualização sobre a composição das espécies de peixes do Parque Nacional da Restinga de Jurubatiba e da lagoa Imboassica, na porção norte do Estado do Rio de Janeiro, com base em esforços de coleta de quase duas décadas, registros históricos em museus, e uma revisão da literatura. Métodos: Os espécimes foram coletados através de uma variedade de técnicas, principalmente entre 1994 e 2012, e foram fixados com a utilizaçáo de uma soluçáo de formalina a $10 \%$, sendo subsequentemente armazenados em solução de álcool a $70 \%$. Todos os espécimes examinados foram depositados nas coleçóes de peixes do Núcleo em Ecologia e Desenvolvimento Socioambiental de Macaé, Universidade Federal do Rio de Janeiro (NPM), e Museu Nacional, Universidade Federal do Rio de Janeiro (MNRJ). Espécies de peixes continentais (água doce) e algumas espécies marinhas ou estuarinas frequentemente coletadas foram consideradas como Residentes, enquanto espécies marinhas coletadas apenas esporadicamente foram consideradas como Ocasionais. Possíveis associaçóes entre a orientação das lagoas e a composição de peixes Residentes foram exploradas através de uma Análise de Correspondência (CA). Resultados: Um total de 100 espécies, pertencentes a 19 ordens e 41 famílias de Teleostei, foi registrado. Quando espécies Residentes e Ocasionais são consideradas, as famílias Carangidae e Engraulidae, com nove e oito espécies respectivamente, são as mais representativas. Quando apenas espécies Residentes são consideradas, Gerreidae e Gobiidae, ambas com sete espécies, são as mais representativas. A lagoa Imboassica, com 76 espécies, possui a maior riqueza de espécies entre as lagoas incluídas neste estudo. Um total de 81 espécies foi registrado no Parque Nacional da Restinga de Jurubatiba, um número duas vezes maior do que o relatado em estudos anteriores. Uma chave de identificação, incluindo 57 espécies Residentes, também é apresentada. Conclusóes: Lagoas Paralelas foram caracterizadas por um pequeno grupo de espécies continentais presumivelmente de ancestralidade marinha (Divisão Secundária), enquanto espécies marinhas foram mais representativas em lagoas Ortogonais. A maior frequência de espécies marinhas em lagoas Ortogonais pode estar associada com aberturas da barra arenosa. Conexóes temporárias e esporádicas entre lagoas Paralelas durante períodos de maior pluviosidade podem promover uma maior similaridade em termos de composição de espécies.

Palavras-chave: diversidade, ambientes costeiros, PELD, espécies introduzidas, chave de identificação.

\section{Introduction}

Several coastal lagoons that vary in terms of size, shape, limnology and composition of their aquatic community are found in the northern portion of Rio de Janeiro State. Eighteen of them are located in the Restinga de Jurubatiba National Park (PARNA Jurubatiba; Figure 1), a relatively well-preserved portion of the coast with about 14,860 ha between the cities of Macaé and Quissamã. Fishes of those lagoons have been sporadically studied since the beginning of the XIX century. Charles Darwin, for instance, collected a specimen in 1832 at "Lagoa de Boacica" (=Imboassica), which was identified by Jenyns (1842) as Gerres gula and is now valid as Eucinostomus gula (Quoy and Gaimard, 1824).

More in-depth studies on the fish composition of the lagoons of the northern Rio de Janeiro State started to be conducted only at the end of the XX century. Aguiaro and Caramaschi (1995) presented a short list of species of the Teleostei collected in two lagoons (Cabiúnas and Comprida) of the Restinga de Jurubatiba before the establishment of the National Park in 1998. Hollanda-Carvalho et al.
(2003) identified 21 species belonging to 13 families and six orders in seven lagoons of the Park, which were collected during the dry (August 2001) and rainy (February 2002) seasons. One interesting aspect noted by those authors is that a substantial portion of the species identified (76\%) belonged to the Primary and Secondary Divisions of Myers (1938), suggesting that the fish composition of the lagoons of the Park were largely influenced by freshwater (continental) environments. Based on additional samplings on those lagoons, coupled with a thorough review of the literature and the examination of specimens deposited in fish collections, Caramaschi et al. (2004) identified 39 species in 11 lagoons of the Park. In opposition to Hollanda-Carvalho et al. (2003), Caramaschi et al. (2004) found that about half (20) of those species should be regarded as marine, indicating that the fish composition of the lagoons of the Restinga de Jurubatiba National Park seems to be more balanced between a continental and marine origin. 
The Imboassica Lagoon, located in the southern portion of the city of Macaé, RJ (Figure 1), is similar in terms of geological history and geomorphology to the lagoons of the Restinga de Jurubatiba National Park. However, contrary to the other lagoons included in this study, the Imboassica Lagoon is not located in the Park. Consequently, that lagoon has been subjected to a series of human impacts that include the artificial opening of its sandbar which promotes a connection to the sea, the discharge of domestic and possibly industrial effluents, and an increase in the deposition of sediments resulting from removal of the original riparian vegetation along its tributaries and the lagoon itself. Its fish community and limnology has been more extensively studied, though, perhaps providing additional information on the fishes that might inhabit the less explored coastal lagoons of the region. Saad et al. (2002), for instance, identified 35 species in the Imboassica Lagoon, with 26 of them (about $75 \%$ ) regarded as predominantly marine. Caramaschi et al. (2004) identified 67 species of the Teleostei belonging to 31 families and 14 orders in the Imboassica Lagoon. About $85 \%$ of those species are marine, and the occurrence of several of them was regarded by Caramaschi et al. (2004) as sporadic and related to events of sandbar breaching.

The species richness of the coastal lagoons of the northern Rio de Janeiro State varies according to their geological history, which largely defines the physical hydrological connections (permanent or temporary) between different water bodies, such as rivers, other lagoons, and the sea (SánchezBotero et al., 2009; De Macedo-Soares et al., 2010).

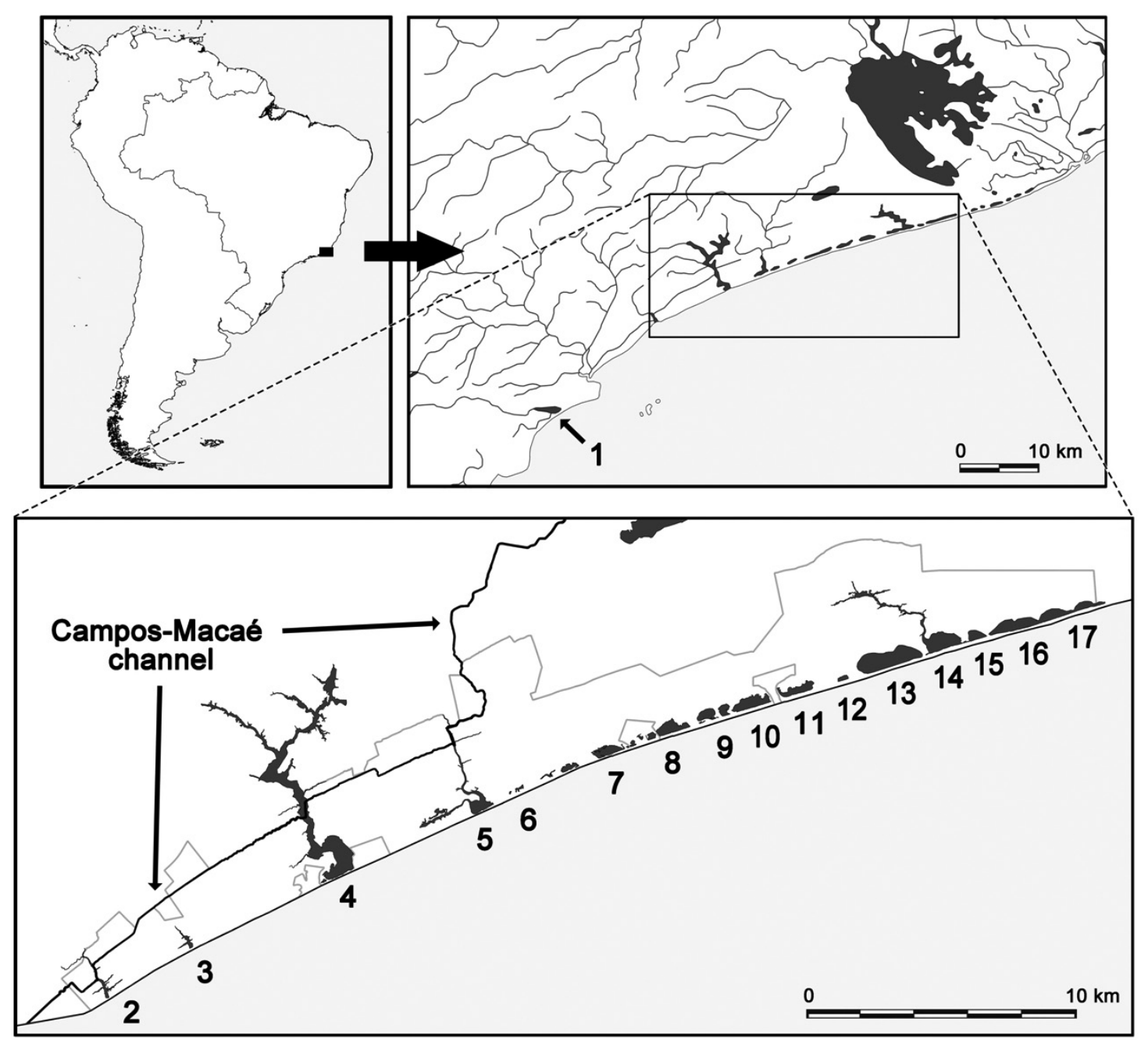

Figure 1. Position and physical configuration of the 17 lagoons included in this study. Boundaries of the Restinga de Jurubatiba National Park are indicated by the grey line in the lower inset; the Campos-Macaé channel is indicated by the darker line in the same figure. Lagoons are numbered as follows: 1) Imboassica (upper right inset), 2) Cabiúnas, 3) Comprida, 4) Carapebus, 5) Paulista, 6) Amarra Boi, 7) Garças, 8) Piripiri, 9) Maria Menina, 10) Robalo, 11) Visgueiro, 12) Catingosa, 13) Pires, 14) Preta, 15) Barrinha, 16) Casa Velha, and 17) Ubatuba. 
Those connections are also modulated by variations in rainfall, which is typically higher between October and March, and lower between April and September in the region (De Macedo-Soares et al., 2010). Variations in the rainfall regime among different years and the orientation of the longest axis of those lagoons in relation to the coastline also affect their depth and salinity (Caliman et al., 2010). The deepest lagoons are typically those whose main axis is oriented perpendicularly to the coastline, and are herein referred to as Orthogonal lagoons: the Imboassica, Cabiúnas, Comprida, Carapebus, Paulista and Preta lagoons (Figure 1, lagoons 1-5 and 14). Orthogonal lagoons are less influenced by the sea in terms of salinity, because they receive freshwater inputs from their catchment area and have a short extent of their perimeter close to the sea (Caliman et al., 2010). Aquatic macrophytes typically abound in the lateral and distal (opposite to the sea) portions of Orthogonal lagoons, and they are more prone to events of sandbar breaching in years of intense rainfall. The longest axes of the remaining lagoons of the Restinga de Jurubatiba National Park are parallel to the coastline (Caliman et al., 2010), and they are therefore referred to as Parallel lagoons. Those lagoons are the Encantada, Amarra Boi, Bezerra, Garças, Piripiri, Maria Menina, Robalo, Visgueiro, Catingosa, Pires, Barrinha, Casa Velha, and Ubatuba (Figure 1, lagoons 6-14 and 16-17). Parallel lagoons are typically shallow and have a larger content of diluted salts. The aquatic vegetation, when present, is more evenly distributed and typically dominated by algae and the monocotyledon Ruppia maritima (Bove and Paz, 2009).

The aim of this paper is to present an update on the composition of the fish species (Teleostei) of the lagoons of the Restinga de Jurubatiba National Park and the Imboassica Lagoon. Those lagoons have been the focus of several unpublished studies in the last decade, which substantially improved the knowledge on the main aspects of the taxonomy and ecology of their fish fauna. The northern portion of the Rio de Janeiro State is also experiencing a fast increase in terms of population and economy, as a consequence of the exploitation of petroleum reserves in the Campos Marine Basin. This unplanned urbanization process resulted in drastic alterations on most ecosystems, and a more refined knowledge on the fish fauna of the lagoons of the region is necessary for management strategies. A comparison between the fish composition of the Imboassica Lagoon, on the one hand, and that of the lagoons located in the Restinga de Jurubatiba National Park, on the other, might also offer insights into the consequences of the human generated impacts into the fish fauna of those environments. In order to foster further studies, an identification key including all resident species of Teleostei that have been so far identified in those lagoons is also presented.

\section{Material and Methods}

Specimens were collected using a variety of techniques, mostly between 1994 and 2012 . Marginal portions of the lagoons, especially those adjacent to the sandbar, were sampled with a 5 meter-long seine, $5 \mathrm{~mm}$ mesh size, and hand nets. Casting nets and gill nets with 15, 20, 25, 35, 40 and $45 \mathrm{~mm}$ mesh sizes were also employed in the deeper, more central or lateral portions of the lagoons, specially the Orthogonal ones. Sampling effort was variable, and mostly related to the size of the lagoon and their structural complexity. Lagoons were sampled semiannually between 1999 and 2009, in the first phase of the "Programa de Pesquisas Ecológicas de Longa Duração (Long Term Ecological Research Program) - PELD - Site 5”. The Cabiúnas and Comprida lagoons were also sampled semiannually between 2010 and 2012, as they were the focus of the second phase of PELD Site 5.

Specimens collected were fixed with the use of a $10 \%$ solution of formalin and subsequently stored in $70 \%$ alcohol solution. Identifications were carried out with the use of several taxonomic guides, original species descriptions, and comparisons with previously identified specimens deposited in fish collections, especially that of the Museu Nacional, Universidade Federal do Rio de Janeiro (MNRJ). A list including all the literature used in specimen identification is not provided, since it would be too extensive, but Reis et al. (2003) and Menezes et al. (2007) were used as indicative of the species occurring in the region. Ordinal and familial classifications follow Wiley and Johnson (2010), whereas names of genera and species follow Eschmeyer (2013). All specimens examined in this study (see Appendix) are deposited in the fish collections of the Núcleo em Ecologia e Desenvolvimento Socioambiental de Macaé, Universidade Federal do Rio de Janeiro (NPM), and MNRJ.

Additional information on the occurrence of some species in the lagoons of the Restinga de Jurubatiba National Park and Imboassica Lagoon was also compiled from previously published and 
unpublished studies (Hollanda-Carvalho et al., 2003; Caramaschi et al., 2004; Camara, 2010). Fishes were regarded as Resident or Occasional. Resident species are those of the Primary and Secondary Divisions of Myers (1938), as well as some marine or estuarine species that are frequently collected in the lagoons (Peripheral freshwater fishes sensu Nichols, 1928). Marine species collected only sporadically in the lagoons were regarded as Occasional. The identification key includes all 57 Resident species identified in the 17 lagoons and the two unnamed pools studied.

\subsection{Data analyses}

Possible associations between the orientation of the lagoons (Parallel or Orthogonal to the coastline) and the composition of Resident fishes were explored through a Correspondence Analysis (CA). A matrix of presence versus absence of Resident species in each of the 17 lagoons included in this study was constructed, excepting the three species that were found exclusively in the pools. In the analysis, each lagoon was considered as a sample, and the composition of species of each lagoon was inferred based exclusively on species scored for that lagoon. The CA ordered the lagoons according to the composition of species, and also ordered the species according to their presence in those same lagoons. Only the first axis of the CA was considered, since it presented an eigenvalue larger than 0.20 (Matthews, 1998) and also presented an arch effect, even after the attribution of a smaller weight to rare species. Considering the differences detected in the segregation of samples according to the specific composition shown by the CA, scores of CA 1 were compared between the Orthogonal and Parallel lagoons through the Mann-Whitney test, since the assumptions of normality and homoscedasticity of the Student's t-test were not achieved even after the data transformation.

Caliman et al. (2010) concluded that the area size and salinity of the lagoons are probably the main factors that characterize them in terms of limnology. Those authors also concluded that the spatial configuration strongly influences the susceptibility of a lagoon to the intrusion of marine water, through events of sandbar breaching in Orthogonal lagoons or the intrusion of sea water over the sandbanks in Parallel lagoons. Since correlations between the area size of the lagoons and their salinity were not found $(\mathrm{r}=-0.11 ; \mathrm{p}=0.68)$, each of these variables were analyzed separately in relation to the total richness of Resident species and to the relative proportion among marine fishes, fishes of the Primary Division, and fishes of the Secondary Division of Myers (1938) scored for each lagoon. Dimensions of the lagoons and their levels of salinity were based on Caliman et al. (2010) and De Macedo-Soares et al. (2010). We also used an expanded concept of Secondary Division, and included in that Division four species of predominantly-marine families that are actually more associated or totally restricted to estuarine/coastal freshwater environments. Those species are the clupeid Platanichthys platana, the syngnathids Microphis lineatus and Pseudophallus mindii, and the eleotrid Eleotris pisonis. Pools were excluded from the analyses due to their uniqueness in species composition. Values of area size were transformed $\left(\log _{10}\right)$ in order to achieve normality (Shapiro Wilk Test). The ordination and univariate tests (correlations and median test) were performed by the program PC-Ord 4.10 (McCune and Mefford, 1999) and Statistica ${ }^{\text {TM }}$ (Statsoft, 2007) respectively. The significance level in the tests was considered as $\alpha=0.05$.

\section{Results}

\subsection{Summary of the fishes of the Imboassica Lagoon and the Restinga de Jurubatiba National Park}

A total of 100 species of fishes were recorded in the Imboassica Lagoon and in the Restinga de Jurubatiba National Park. Fifty-seven of them were regarded as Resident, and the remaining ones as Occasional (Table 1). Those species belong to 19 orders and 41 families of the Teleostei according to the classification of Wiley and Johnson (2010), which is slightly different and, therefore, noncomparable to the suprafamilial classifications adopted in previous studies. When Resident and Occasional species are not discriminated, families with the largest number of species are the Carangidae (nine species), Engraulidae (eight species), Gerreidae and Gobiidae (each with seven species), Characidae (six species), Poeciliidae and Paralichthyidae (each with four species), Clupeidae, Hemiramphidae, Cichlidae, Tetraodontidae and Achiridae (each with three species). The remaining 29 families are represented by only one or two species. With the exception of the Characidae, Poeciliidae, and Cichlidae, families with more than two species recorded are usually regarded as marine. When only Resident species are considered, families with the largest number of species are the Gerreidae and Gobiidae (each with seven species), Characidae (six species), Poeciliidae (four species), 
Table 1. Fishes reported in the lagoons of the Restinga de Jurubatiba National Park and the Imboassica Lagoon, State of Rio de Janeiro, Brazil. Classification follows Wiley and Johnson (2010) and Eschmeyer (2013). Numbers following species are those used in Figure 2. R: Resident; O: Occasional; P: Primary Division; S: Secondary Division; M: Marine.

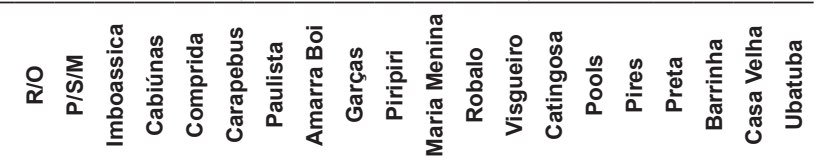

\begin{tabular}{|c|c|c|c|c|c|c|c|c|c|c|c|c|c|c|c|c|c|c|c|}
\hline \multicolumn{20}{|l|}{ Elopiformes } \\
\hline \multicolumn{20}{|l|}{ Elopidae } \\
\hline Elops smithi McBride, Rocha, Ruiz-Carus and Bowen, 2010 & 1 & $\mathrm{O}$ & & $\mathrm{x}$ & & & $x$ & & & & & & & & & & & & \\
\hline \multicolumn{20}{|l|}{ Anguilliformes } \\
\hline \multicolumn{20}{|l|}{ Ophichthidae } \\
\hline Myrophis punctatus Lütken, 1852 & 2 & $\mathrm{O}$ & & $\mathrm{x}$ & & & & & & & & & & & & & & & \\
\hline Ophichthus cylindroideus (Ranzani, 1839) & 3 & $\mathrm{O}$ & & $\mathrm{x}$ & & & & & & & & & & & & & & & \\
\hline \multicolumn{20}{|l|}{ Clupeiformes } \\
\hline \multicolumn{20}{|l|}{ Clupeidae } \\
\hline Harengula clupeola (Cuvier, 1829) & 4 & $\mathrm{O}$ & & $\mathrm{x}$ & & & $\mathrm{x}$ & & & & & & & & & & & & \\
\hline Lile piquitinga (Schreiner and Miranda Ribeiro, 1903) & 5 & $\mathrm{R}$ & M & $\mathrm{x}$ & $\mathrm{x}$ & & $x$ & & & & & & & & & & & & \\
\hline Platanichthys platana (Regan, 1917) & 6 & $\mathrm{R}$ & S & $x$ & $x$ & $\mathrm{x}$ & $x$ & & & & & & $\mathrm{x}$ & & $\mathrm{x}$ & & & & \\
\hline \multicolumn{20}{|l|}{ Engraulidae } \\
\hline Anchoa januaria (Steindachner, 1879) & 7 & $\mathrm{O}$ & & & & & $\mathrm{x}$ & & & & & & & & & & & & \\
\hline Anchoa marinii Hildebrand, 1943 & 8 & $\mathrm{O}$ & & $x$ & & & $x$ & & & & & & & & & & & & \\
\hline Anchoa spinifera (Valenciennes, 1848) & 9 & $\mathrm{O}$ & & & & & $\mathrm{x}$ & & & & & & & & & & & & \\
\hline Anchoa tricolor (Spix and Agassiz, 1829) & 10 & $\mathrm{O}$ & & & & & $x$ & & & & & & & & & & & & \\
\hline Anchovia clupeoides (Swainson, 1839) & 11 & $\mathrm{R}$ & M & $\mathrm{x}$ & $\mathrm{x}$ & & $\mathrm{x}$ & & & & & & $x$ & & $\mathrm{x}$ & & & & \\
\hline Anchoviella lepidentostole (Fowler, 1911) & 12 & $\mathrm{O}$ & & & & & $x$ & & & & & & & & & & & & \\
\hline Cetengraulis edentulus (Cuvier, 1829) & 13 & $\mathrm{O}$ & & $\mathrm{x}$ & & & $x$ & & & & & & & & & & & & \\
\hline Lycengraulis grossidens (Spix and Agassiz, 1829) & 14 & $\mathrm{R}$ & M & $x$ & $\mathrm{x}$ & & $x$ & & & $\mathrm{x}$ & & & & & & & & $\mathrm{x}$ & \\
\hline \multicolumn{20}{|l|}{ Characiformes } \\
\hline \multicolumn{20}{|l|}{ Curimatidae } \\
\hline Cyphocharax gilbert (Quoy and Gaimard, 1824) & 15 & $\mathrm{R}$ & $\mathrm{P}$ & & $\mathrm{x}$ & & $\mathrm{x}$ & $\mathrm{x}$ & & & & & & & & & & & \\
\hline \multicolumn{20}{|l|}{ Erythrinidae } \\
\hline Hoplerythrinus unitaeniatus (Spix and Agassiz, 1829) & 16 & $\mathrm{R}$ & $\mathrm{P}$ & $\mathrm{x}$ & $\mathrm{x}$ & $x$ & $\mathrm{x}$ & $\mathrm{x}$ & $\mathrm{x}$ & $\mathrm{x}$ & $\mathrm{x}$ & & & \multicolumn{6}{|c|}{$\mathrm{x}$} \\
\hline Hoplias malabaricus (Bloch, 1794) & 17 & $\mathrm{R}$ & $\mathrm{P}$ & $x$ & $x$ & $x$ & $\mathrm{x}$ & $x$ & $\mathrm{x}$ & $x$ & $x$ & $x$ & & & & $x$ & & $x$ & $x$ \\
\hline \multicolumn{20}{|l|}{ Characidae } \\
\hline Astyanax bimaculatus (Linnaeus, 1758) & 18 & $\mathrm{R}$ & $P$ & $\mathrm{x}$ & $\mathrm{x}$ & & $\mathrm{x}$ & $x$ & & & $x$ & & & & & & & & \\
\hline Hyphessobrycon bifasciatus Ellis, 1911 & 19 & $\mathrm{R}$ & $P$ & $x$ & $x$ & $x$ & $x$ & $x$ & & $\mathrm{x}$ & $x$ & $\mathrm{x}$ & & & $\mathrm{x}$ & $\mathrm{x}$ & $\mathrm{x}$ & $\mathrm{x}$ & $\mathrm{x}$ \\
\hline Hyphessobrycon luetkenii (Boulenger, 1887) & 20 & $\mathrm{R}$ & $P$ & $x$ & $x$ & $x$ & $x$ & $x$ & & & $x$ & & & & $x$ & & & & \\
\hline Hyphessobrycon reticulatus Ellis, 1911 & 21 & $\mathrm{R}$ & $\mathrm{P}$ & & $x$ & $x$ & $x$ & & & $x$ & $x$ & & & & $\mathrm{x}$ & & & & \\
\hline Metynnis maculatus (Kner, 1858) & 22 & $\mathrm{R}$ & $\mathrm{P}$ & & & & $x$ & & & & & & & & & & & & \\
\hline Oligosarcus hepsetus (Cuvier, 1829) & 23 & $\mathrm{R}$ & $P$ & & $\mathrm{x}$ & & $x$ & & & & & & & & & & & $\mathrm{x}$ & \\
\hline Siluriformes & & & & & & & & & & & & & & & & & & & \\
\hline Ariidae & & & & & & & & & & & & & & & & & & & \\
\hline Genidens genidens (Cuvier, 1829) & 24 & $\mathrm{R}$ & M & $x$ & $x$ & & $x$ & & & & & & & & & & & & \\
\hline Auchenipteridae & & & & & & & & & & & & & & & & & & & \\
\hline Trachelyopterus striatulus (Steindachner, 1877) & 25 & $\mathrm{R}$ & $\mathrm{P}$ & & $\mathrm{x}$ & & $\mathrm{x}$ & $\mathrm{x}$ & & & & & & & & & & & \\
\hline Heptapteridae & & & & & & & & & & & & & & & & & & & \\
\hline Acentronichthys leptos Eigenmann and Eigenmann, 1889 & 26 & $\mathrm{R}$ & $P$ & & & & & & & & & & & $\mathrm{x}$ & & & & & \\
\hline Rhamdia cf. quelen (Quoy and Gaimard, 1824) & 27 & $\mathrm{R}$ & $P$ & $\mathrm{x}$ & $\mathrm{x}$ & & $x$ & & & & & & & & $\mathrm{x}$ & & & & \\
\hline Callichthyidae & & & & & & & & & & & & & & & & & & & \\
\hline Callichtys callichtys (Linnaeus, 1758) & 28 & $\mathrm{R}$ & $P$ & & $x$ & & & & & & $x$ & & & & & & & & \\
\hline Hoplosternum littorale (Hancock 1828) & 29 & $\mathrm{R}$ & $P$ & $x$ & & & $x$ & & & & & & & & & & & & \\
\hline Gymnotiformes & & & & & & & & & & & & & & & & & & & \\
\hline Hypopomidae & & & & & & & & & & & & & & & & & & & \\
\hline $\begin{array}{l}\text { Brachyhypopomus janeiroensis } \\
\text { (Costa and Campos-da-Paz, 1992) }\end{array}$ & 30 & $\mathrm{R}$ & $P$ & & & $x$ & & & & & & & & & & $x$ & & & \\
\hline Gymnotidae & & & & & & & & & & & & & & & & & & & \\
\hline Gymnotus aff. carapo Linnaeus, 1758 & 31 & $\mathrm{R}$ & $P$ & & & & & & & & & & & $x$ & & & & & \\
\hline Mugiliformes & & & & & & & & & & & & & & & & & & & \\
\hline Mugilidae & & & & & & & & & & & & & & & & & & & \\
\hline Mugil curema Valenciennes, 1836 & 32 & $\mathrm{R}$ & M & $\mathrm{x}$ & $x$ & & $x$ & $x$ & & & & & & & & & & & \\
\hline Mugil liza Valenciennes, 1836 & 33 & $\mathrm{R}$ & M & $x$ & $x$ & & $x$ & & & & & & & & & & & & \\
\hline Synbranchiformes & & & & & & & & & & & & & & & & & & & \\
\hline
\end{tabular}


Table 1. Continued...

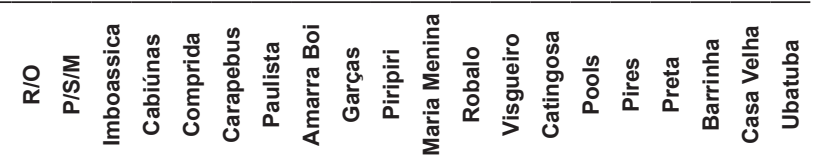

\section{Synbranchidae}

Synbranchus aff. marmoratus Bloch, 1795

\section{Gasterosteiformes}

Syngnathidae

Microphis lineatus (Kaup, 1856)

Pseudophallus mindii (Meek and Hildebrand, 1923)

\section{Atheriniformes}

Atherinopsidae

Atherinella brasiliensis (Quoy and Gaimard, 1825)

\section{Beloniformes}

Belonidae

Strongylura marina (Walbaum, 1792)

Strongylura timucu (Walbaum, 1792)

Hemiramphidae

Hemiramphus brasiliensis (Linnaeus, 1758)

Hyporhamphus roberti (Valenciennes, 1847)

Hyporhamphus unifasciatus (Ranzani, 1841)

\section{Cyprinodontiformes}

Rivulidae

Atlantirivulus jurubatibensis (Costa, 2008)

Anablepidae

Jenynsia multidentata (Jenyns, 1842)

Poeciliidae

Phalloceros harpagos Lucinda, 2008

Phalloptychus januarius (Hensel, 1868)

Poecilia reticulata Peters, 1859

Poecilia vivipara Bloch and Schneider, 1801

\section{Carangiformes}

Carangidae

Caranx bartholomaei (Cuvier, 1833)

Caranx hippos (Linnaeus, 1766)

Caranx latus Agassiz, 1831

Chloroscombrus chrysurus (Linnaeus, 1766)

Hemicaranx amblyrhynchus (Cuvier, 1833)

Oligoplites saurus (Bloch and Schneider, 1801)

Pseudocaranx dentex (Bloch and Schneider, 1801)

Trachinotus carolinus (Linnaeus, 1766)

Trachinotus falcatus (Linnaeus, 1758)

\section{Dactylopteriformes}

Dactylopteridae

Dactylopterus volitans (Linnaeus, 1758)

\section{Gobiiformes}

Eleotridae

Eleotris pisonis (Gmelin, 1789)

Gobiidae

Awaous tajasica (Lichtenstein, 1822)

Bathygobius soporator (Valenciennes, 1837)

Ctenogobius boleosoma (Jordan and Gilbert, 1882)

Ctenogobius shufeldti (Jordan and Eigenmann, 1887)

Ctenogobius stigmaticus (Poey, 1860)

Evorthodus lyricus (Girard, 1858)

Gobionellus oceanicus (Pallas, 1770)

\section{Labriformes}

Cichlidae

Australoheros cf. macaensis Ottoni and Costa, 2008

Geophagus brasiliensis (Quoy and Gaimard, 1824)

Tilapia rendalli (Boulenger, 1897)
$34 \mathrm{R} \quad \mathrm{S} \times \mathrm{x}$

$\begin{array}{lllll}35 & R & S & x & \\ 36 & R & S & x & x\end{array}$

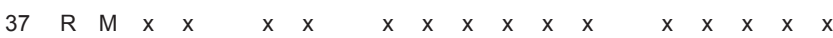

$\begin{array}{lllll}38 & 0 & x & & x \\ 39 & 0 & x & x & x \\ 40 & 0 & & & x \\ 41 & 0 & & & x \\ 42 & 0 & x & & \end{array}$

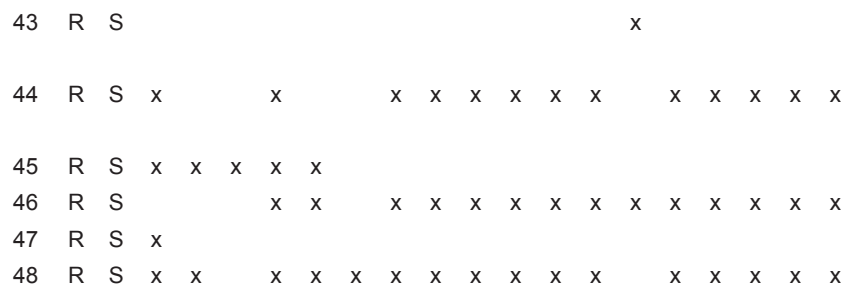

$\begin{array}{llll}49 & 0 & x & x \\ 50 & 0 & x & x \\ 51 & 0 & x & x \quad x \\ 52 & 0 & & x \\ 53 & 0 & & x \\ 54 & 0 & x & x \\ 55 & 0 & & x \\ 56 & 0 & x & x \\ 57 & 0 & x & x\end{array}$

$580 \quad x \quad x$

59 R S x

$60 \mathrm{R} M \quad \mathrm{M} \times \mathrm{x} \quad \mathrm{x}$

61 R $M \quad x \quad x$

$62 \mathrm{R} M \quad \mathrm{M} \quad \mathrm{x} \quad \mathrm{x}$

$63 \mathrm{R} M \mathrm{X}$

$64 \mathrm{R} M \quad \mathrm{x}$

$65 \mathrm{R} \quad \mathrm{M} \quad \mathrm{x}$

$66 \mathrm{R} M \quad \mathrm{M} \times \mathrm{x} \quad \mathrm{x}$

$\begin{array}{lllllllllllllllllllllllllll}67 & \mathrm{R} & \mathrm{S} & & & \mathrm{x} & \mathrm{x} & \mathrm{x} & \mathrm{x} & & & & & & & & & & & & & & & & & & \\ 68 & \mathrm{R} & \mathrm{S} & \mathrm{x} & \mathrm{x} & \mathrm{x} & \mathrm{x} & \mathrm{x} & \mathrm{x} & \mathrm{x} & \mathrm{x} & & \mathrm{x} & \mathrm{x} & \mathrm{x} & & \mathrm{x} & \mathrm{x} & & \mathrm{x} & \mathrm{x} \\ 69 & \mathrm{R} & \mathrm{S} & \mathrm{x} & & \mathrm{x} & \mathrm{x} & & & & & \mathrm{x} & \mathrm{x} & \mathrm{x} & & \mathrm{x} & & \mathrm{x} & & \mathrm{x} & & \mathrm{x}\end{array}$


Table 1. Continued...

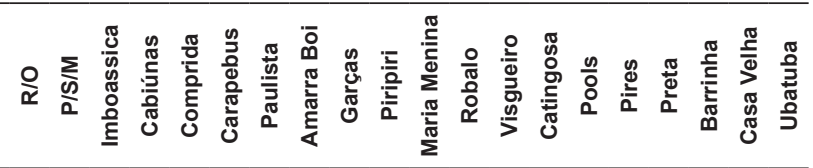

\begin{tabular}{|c|c|c|c|c|c|c|c|c|}
\hline Pomacentridae & & & & & & & & \\
\hline Abudefduf saxatilis (Linnaeus, 1758) & 70 & 0 & & $\mathrm{x}$ & & & & \\
\hline "Perciformes" & & & & & & & & \\
\hline Centropomidae & & & & & & & & \\
\hline Centropomus parallelus Poey, 1860 & 71 & $\mathrm{R}$ & M & $x$ & $x \quad x$ & $\mathrm{x}$ & $\mathrm{x}$ & \\
\hline Centropomus undecimalis (Bloch, 1792) & 72 & $\mathrm{R}$ & M & $x$ & $\mathrm{x}$ & $\mathrm{x}$ & & \\
\hline Pomatomidae & & & & & & & & \\
\hline Pomatomus saltatrix (Linnaeus, 1766) & 73 & 0 & & $x$ & & & & \\
\hline Lutjanidae & & & & & & & & \\
\hline Lutjanus jocu (Bloch and Schneider, 1801) & 74 & 0 & & $\mathrm{x}$ & & & & \\
\hline Gerreidae & & & & & & & & \\
\hline Diapterus auratus Ranzani, 1842 & 75 & $R$ & $\mathrm{M}$ & $x$ & $\mathrm{x}$ & & & \\
\hline Diapterus rhombeus (Cuvier, 1829) & 76 & $\mathrm{R}$ & M & $x$ & $x$ & $\mathrm{x}$ & & \\
\hline Eucinostomus argenteus Baird and Girard, 1855 & 77 & $\mathrm{R}$ & M & $x$ & $x$ & $x$ & $x$ & \\
\hline Eucinostomus gula (Quoy and Gaimard, 1824) & 78 & $\mathrm{R}$ & M & $\mathrm{x}$ & & & & \\
\hline Eucinostomus melanopterus (Bleeker, 1863) & 79 & $\mathrm{R}$ & M & $\mathrm{x}$ & & & & \\
\hline Eugerres brasilianus (Cuvier, 1830) & 80 & $\mathrm{R}$ & M & $x$ & $\mathrm{x}$ & $\mathrm{x}$ & & \\
\hline Ulaema lefroyi (Goode, 1874) & 81 & $\mathrm{R}$ & M & & $x$ & $x$ & $x$ & \\
\hline Haemulidae & & & & & & & & \\
\hline Conodon nobilis (Linnaeus, 1758) & 82 & $\mathrm{O}$ & & $\mathrm{x}$ & $x$ & $x$ & & \\
\hline Pomadasys crocro (Cuvier, 1830) & 83 & 0 & & $x$ & & $x$ & & \\
\hline Sparidae & & & & & & & & \\
\hline Archosargus probatocephalus (Walbaum, 1792) & 84 & 0 & & $\mathrm{x}$ & & & & \\
\hline Sciaenidae & & & & & & & & \\
\hline Micropogonias furnieri (Desmarest, 1823) & 85 & 0 & & $x$ & & $x$ & $x$ & $x$ \\
\hline Stellifer brasiliensis (Schultz, 1945) & 86 & $\mathrm{O}$ & & $x$ & & & & \\
\hline Polynemidae & & & & & & & & \\
\hline Polydactylus oligodon (Günther, 1860) & 87 & 0 & & $x$ & & & & \\
\hline Polydactylus virginicus (Linnaeus, 1758) & 88 & 0 & & $\mathrm{x}$ & & $\mathrm{x}$ & & \\
\hline Pleuronectiformes & & & & & & & & \\
\hline Paralichthyidae & & & & & & & & \\
\hline Citharichthys arenaceus Evermann and Marsh, 1900 & 89 & $\mathrm{R}$ & M & $x$ & & $\mathrm{x}$ & & \\
\hline Citharichthys spilopterus Günther, 1862 & 90 & $\mathrm{R}$ & M & $x$ & $\mathrm{x}$ & & & \\
\hline Paralichthys brasiliensis (Ranzani, 1842) & 91 & 0 & & $\mathrm{x}$ & & & & \\
\hline Paralichthys orbignyanus (Valenciennes, 1839) & 92 & $\mathrm{O}$ & & $\mathrm{x}$ & & & & \\
\hline Achiridae & & & & & & & & \\
\hline Achirus lineatus (Linnaeus 1758) & 93 & $\mathrm{O}$ & & $\mathrm{x}$ & & & & \\
\hline Trinectes microphthalmus (Chabanaud, 1928) & 94 & $\mathrm{R}$ & M & $\mathrm{x}$ & & $x$ & & \\
\hline Trinectes paulistanus (Miranda Ribeiro, 1915) & 95 & $\mathrm{R}$ & M & $x$ & $\mathrm{x}$ & $x$ & & \\
\hline Tetraodontiformes & & & & & & & & \\
\hline Monacanthidae & & & & & & & & \\
\hline Stephanolepis hispidus (Linnaeus, 1766) & 96 & 0 & & & & $x$ & & \\
\hline Tetraodontidae & & & & & & & & \\
\hline Lagocephalus laevigatus (Linnaeus, 1766) & 97 & $\mathrm{O}$ & & $x$ & & & & \\
\hline Sphoeroides pachygaster (Müller and Troschel, 1848) & 98 & $\mathrm{O}$ & & $\mathrm{x}$ & & $x$ & & \\
\hline Sphoeroides testudineus (Linnaeus, 1758) & 99 & 0 & & $\mathrm{x}$ & & $x$ & & \\
\hline Diodontidae & & & & & & & & \\
\hline Chilomycterus spinosus (Linnaeus, 1758) & 100 & 0 & & $x$ & & & & \\
\hline
\end{tabular}

and Cichlidae (three species). Those families are generally regarded as including fishes of the Primary and Secondary Divisions of Myers (1938), with the exception of the Gerreidae and Gobiidae. The Otophysi, by far the most diverse group of primarily freshwater fishes in the Neotropical region, accounts for 17 species of the fishes of the lagoons studied.
The Characiformes, with nine species, is the most representative order of the Otophysi, followed by the Siluriformes, with six species, and the Gymnotiformes, with only two species.

The Imboassica Lagoon, with 76 species, is the most diverse in terms of species of fishes among the lagoons included in this study, when both 
Resident and Occasional species are considered. This result reflects, at least partially, the intensity in which this lagoon has been studied in the last decades. Nineteen of all the 100 species recorded were found exclusively in the Imboassica Lagoon. Most of those species are regarded as Occasional and probably entered the Imboassica after events of sandbar breaching, which are relatively frequent in this unprotected and highly impacted lagoon. That is almost certainly the case of the halfbeak Hyporhamphus unifasciatus, the sergeant Abudefduf saxatilis, the bluefish Pomatomus saltatrix, the snapper Lutjanus jocu, the porgy Archosargus probatocephalus, the threadfin Polydactylus oligodon, the soles Paralichthys brasiliensis, P. orbignyanus and Achirus lineatus, and the puffers Lagocephalus laevigatus and Chilomycterus spinosus, which are marine species relatively common in the region. However, some species reported exclusively in the Imboassica Lagoon are typical inhabitants of continental coastal environments, and they might also occur in the comparatively less studied lagoons of the Restinga de Jurubatiba National Park. That is possibly the case of the ophichthids Myrophis punctatus and Ophichthus cylindroideus. Three species, in particular, are also relatively common in environments similar to the lagoons of the Restinga de Jurubatiba National Park, and therefore their occurrence in the Park is highly probable: the pipefish Microphis lineatus, the eleotrid Eleotris pisonis, and the guppy Poecilia reticulata, which is a species native to the northern portion of South America and Caribbean Islands (Lucinda, 2003).

Eighty-one species of fishes were recorded in the lagoons and pools of the Restinga de Jurubatiba National Park. Those species belong to 18 orders and 34 families of the Teleostei. When only the fishes recorded in the Jurubatiba National Park are considered, families with the largest number of species are the Carangidae (nine species), Engraulidae (eight species), Gobiidae (seven species), Characidae (six species), Gerreidae (five species), and the Clupeidae, Poeciliidae, and Cichlidae (each with three species). All other families are represented by only one or two species. Fifty-seven of all fishes recorded in the lagoons of the Restinga de Jurubatiba National Park were regarded as Residents. When only Resident species are considered, families with the largest number of species are the Gobiidae (seven species), Characidae (six species), Gerreidae (five species), and the Poeciliidae and Cichlidae (each with three species). The other 19 families with Resident species recorded in the lagoons of the Restinga de Jurubatiba National Park are represented by one or two species. The Otophysi is represented by 17 species, which corresponds to about $21 \%$ of all species recorded in the lagoons of the Restinga de Jurubatiba National Park, and $29.8 \%$ when only Resident species are considered.

Seventy species of fishes, including Resident and Occasional, were recorded in the Carapebus Lagoon. As an anecdotal comparison that illustrates the relatively high fish diversity found in the Restinga de Jurubatiba National Park, the number of species found in the Carapebus Lagoon alone is equivalent to about one-third of all known freshwater fishes of Australia (e.g., Allen, 1989). The Carapebus Lagoon also has the largest number of species that were exclusively recorded in a single lagoon of the Park. With the exception of one species, all the eight species exclusively recorded in the Carapebus Lagoon are marine and relatively common in the region, and were regarded as Occasional. These species are the anchovies Anchoa januaria, A. spinifera, A. tricolor and Anchoviella lepidentostole, the halfbeaks Hemiramphus brasiliensis and Hyporhamphus roberti, and, unexpectedly, the filefish Stephanolepis hispidus, which was collected only on a single occasion. Two other resident species of the Carapebus Lagoon are the non-native pacupeva Metynnis maculatus and the African tilapia, Tilapia rendalli.

The Cabiúnas Lagoon, with 37 species, is the second lagoon of the Restinga de Jurubatiba National Park in terms of number of species recorded, followed by the Paulista Lagoon, with 20 species, and Garças, Piripiri, Pires and Comprida, each one with only 13 registered species. The other lagoons of the Park included in this study have less than ten recorded species. As the sampling effort was unequal among lagoons, those numbers are merely descriptive and might underestimate the presumed diversity of at least some lagoons. Three species, for instance, were exclusively recorded in freshwater pools (Pools in Table 1), adjacent to the Piripiri and Catingosa lagoons. One of them is the Near Threatened Atlantirivulus jurubatibensis, which up to this day is the only known endemic species of fish recorded in the Restinga de Jurubatiba National Park.

\subsection{Species richness and possible correlations with area and salinity}

The local richness of species is typically higher in Orthogonal lagoons among the lagoons studied 
Table 2. Lagoons included in this study in relation to their orientation to the sea, location, area, salinity, total species richness and ratio of Resident species. Code refers to the identification of each lagoon in the Figures.

\begin{tabular}{|c|c|c|c|c|c|c|c|c|}
\hline \multirow{2}{*}{ Lagoon } & \multirow{2}{*}{ Code } & \multirow{2}{*}{$\begin{array}{l}\text { Landscape } \\
\text { position }\end{array}$} & \multicolumn{2}{|c|}{ Coordinates } & \multirow{2}{*}{$\begin{array}{l}\text { Area } \\
\left(\mathbf{k m}^{2}\right)\end{array}$} & \multirow{2}{*}{ Salinity } & \multirow{2}{*}{$\begin{array}{c}\text { Total } \\
\text { richness }\end{array}$} & \multirow{2}{*}{$\begin{array}{l}\text { Resident species } \\
\text { (ratio) }\end{array}$} \\
\hline & & & Latitude & Longitude & & & & \\
\hline Imboassica & 1 & Orthogonal & -22.81 & -41.82 & 2.60 & 3.52 & 76 & 0.57 \\
\hline Cabiúnas & 2 & Orthogonal & -22.58 & -41.69 & 0.34 & 1.01 & 36 & 0.95 \\
\hline Comprida & 3 & Orthogonal & -22.55 & -41.66 & 0.11 & 0.13 & 13 & 1.00 \\
\hline Carapebus & 4 & Orthogonal & -22.48 & -41.60 & 4.11 & 5.31 & 69 & 0.59 \\
\hline Paulista & 5 & Orthogonal & -22.45 & -41.54 & 1.41 & 2.27 & 18 & 0.95 \\
\hline Amarra Boi & 6 & Parallel & -22.44 & -41.52 & 0.22 & 0.27 & 4 & 1.00 \\
\hline Garças & 7 & Parallel & -22.41 & -41.49 & 0.21 & 31.22 & 13 & 0.92 \\
\hline Piripiri & 8 & Parallel & -22.40 & -41.47 & 1.17 & 17.00 & 13 & 1.00 \\
\hline Maria Menina & 9 & Parallel & -22.38 & -41.45 & 0.60 & 15.31 & 5 & 1.00 \\
\hline Robalo & 10 & Parallel & -22.38 & -41.43 & 1.25 & 25.05 & 8 & 1.00 \\
\hline Visgueiro & 11 & Parallel & -22.37 & -41.41 & 1.21 & 28.41 & 5 & 1.00 \\
\hline Catingosa & 12 & Parallel & -22.37 & -41.40 & 0.09 & 25.31 & 9 & 1.00 \\
\hline Pires & 13 & Parallel & -22.35 & -41.38 & 1.59 & 17.39 & 13 & 0.92 \\
\hline Preta & 14 & Orthogonal & -22.34 & -41.36 & 1.94 & 7.51 & 8 & 1.00 \\
\hline Barrinha & 15 & Parallel & -22.34 & -41.35 & 0.28 & 11.4 & 7 & 1.00 \\
\hline Casa Velha & 16 & Parallel & -22.33 & -41.33 & 0.53 & 8.98 & 9 & 1.00 \\
\hline Ubatuba & 17 & Parallel & -22.31 & -41.31 & 0.34 & 7.99 & 8 & 1.00 \\
\hline
\end{tabular}

(Table 2). Relatively higher values of Occasional species were recorded in the Imboassica (43\%) and Carapebus (41\%) lagoons. Species recorded in the other lagoons, regardless of their orientation, are mostly Residents (values higher than 92\%).

An analysis of the specific composition of the Resident species (excluding those found exclusively in the pools) revealed a strong pattern of segregation of the lagoons. Two larger clusters are recognizable in the space between the two axes of the CA: one of them is formed by the Orthogonal lagoons, with positive scores, whereas the other cluster, with negative scores, is formed by the Parallel lagoons with the exception of the Preta Lagoon (Figure 2A). A small group of fishes composed by Phalloptychus januarius, Jenynsia multidentata, Brachyhypopomus janeiroensis, Poecilia vivipara, Atherinella brasiliensis and Tilapia rendalli influenced the ordination of the Parallel lagoons and the Preta Lagoon, which are more similar among themselves in terms of fish composition when compared to the Orthogonal lagoons. Orthogonal lagoons also share a higher number of Resident species, with values ranging between 8 and 43. However, the co-occurrence of species is not pronounced among Orthogonal lagoons, a condition which determined a higher dispersion of those lagoons along the first two axes of the CA. This result is mostly influenced by the species exclusively recorded in the Imboassica Lagoon, such as Ctenogobius shufeldti, C. stigmaticus, Evorthodus lyricus, Eleotris pisonis, Eucinostomus gula,
E. melanopterus, Microphis lineatus, and Poecilia reticulata (Figure $2 \mathrm{~A}$ and $\mathrm{B}$ ).

Marine species and species of the Secondary Division were more frequent in Orthogonal and Parallel lagoons, respectively. A larger number of marine species in the Imboassica, Cabiúnas and Carapebus lagoons in relation to other Orthogonal lagoons was corroborated according to the scores of CA 1, even though the Preta Lagoon, an Orthogonal lagoon, is more similar to Parallel lagoons in terms of fish composition. Summing up, Parallel and Orthogonal lagoons are significantly different in terms of the composition of Resident species according to the CA (Figure $2 \mathrm{C}$ ).

Area $(\mathrm{r}=0.31 ; \mathrm{N}=17 ; \mathrm{p}=0.22)$ and salinity $(r=-0.32 ; N=17 ; p=0.21)$ of the lagoons were not correlated to the total richness of Resident species. Marine species and those of the Primary Division corresponds only moderately to the total richness, which values lower than $60 \%$ regardless of the size of the lagoons examined. Typically in moderately sized lagoons, with less than $2 \mathrm{~km}^{2}$, fishes of the Secondary Division account for at least half of their total species richness. The Garças and Piripiri lagoons are an exception among the small lagoons, with 33\% and 38\% respectively of their fish community composed by species of the Secondary Division. A correlation between the area of the lagoons and the ratio of species of the Primary or Secondary Divisions, or marine fishes, was also not found (Figure 3). However, a positive correlation between the ratio of species of the Secondary 

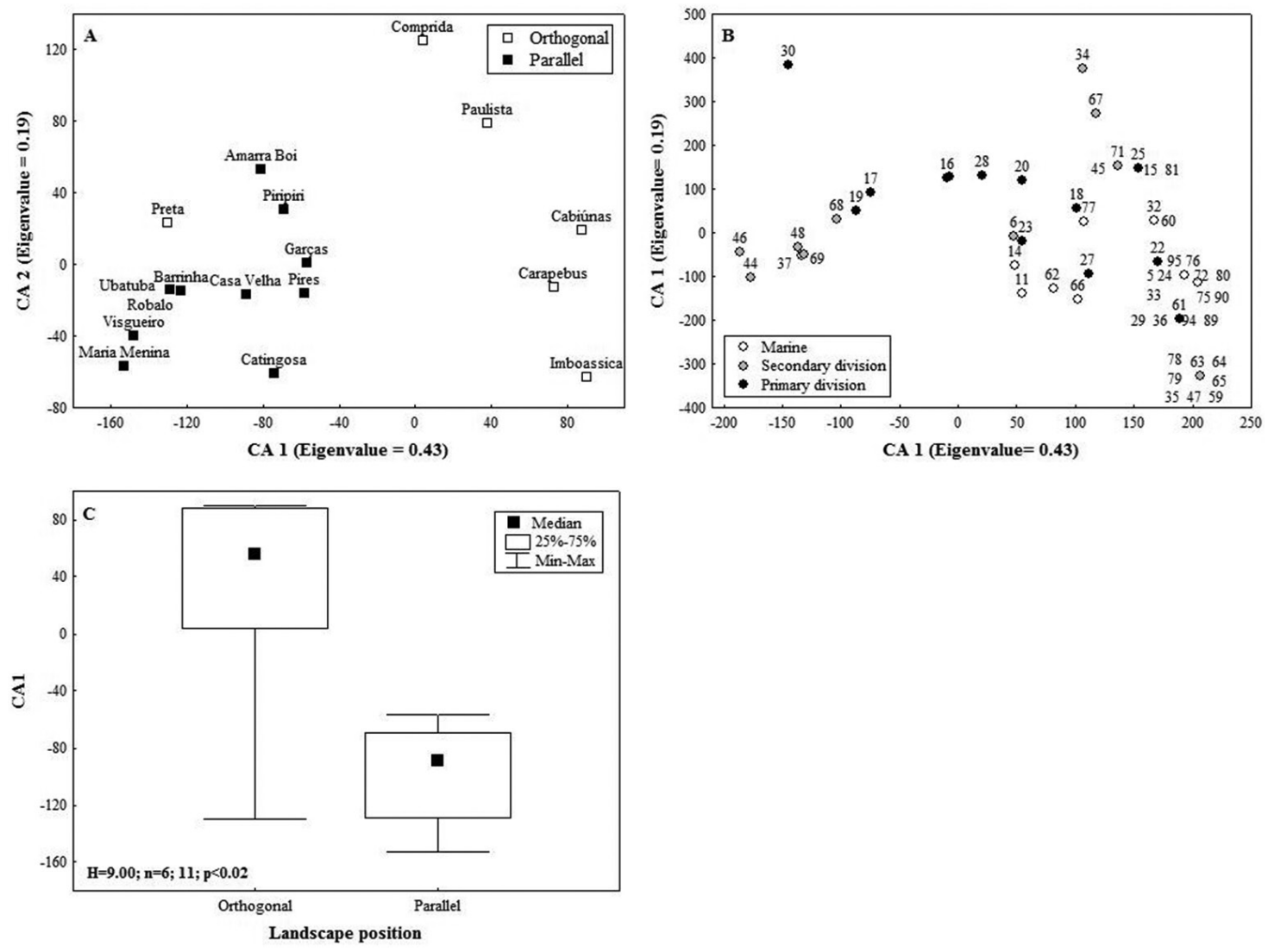

Figure 2. Ordination of lagoons (A) and species (B) along the first two axes of the Correspondence Analysis applied to the data of specific composition and the comparison of the scores of CA 1 retained for interpretation (C). Numbers in (B) refer to species listed in Table 1.

Division and the salinity was found in the analysis. This result highlights the relevance of those species to the composition of the fish community in lagoons with a low richness. Fishes of the Primary Division were only marginally correlated with the salinity, in a negative correlation. Interestingly, the proportion of marine species was not correlated with the salinity of the lagoons (Figure 2).

\section{Discussion}

The total richness of fish species of the Restinga de Jurubatiba National Park is approximately two times higher than indicated in previous studies (e.g., Hollanda-Carvalho et al., 2003; Caramaschi et al., 2004). A more refined knowledge of the diversity of these lagoons clearly reflects the intensity with which they have been studied in the last decade, particularly after the onset of the "PELD, Site 5". A large portion of the continental species of fishes whose occurrences in the region are expected according to their currently known geographic distributions have been actually recorded in this study. We suspect, therefore, that future sampling efforts will mostly result in the documentation of Occasional marine species in the lagoons of the Restinga de Jurubatiba National Park. However, additional, yet unrecorded, Resident fishes might inhabit the relatively less explored lagoons of the Park, such as the Preta, Piripiri, Visgueiro and Catingosa. That is possibly the case of the fat sleeper Dormitator maculatus (Eleotridae), which has been collected in other lagoons of the northern Rio de Janeiro State (e.g., NPM 682 and NPM 772), but so far not in the Imboassica Lagoon or in the Restinga de Jurubatiba National Park. The idea that the Jurubatiba National Park might still harbor some rare species of fishes is evidenced by two small pools (identified as Pools in Table 1) associated to the Piripiri and Catingosa lagoons, which only recently were sampled. The eventual addition of this "hidden diversity" to the list of species of the Park would not substantially modify the total number of recorded species, but would certainly be relevant in terms of conservation in view of their rarity and possible endemism.

Two introduced species have been recorded in the lagoons of the Restinga de Jurubatiba National 

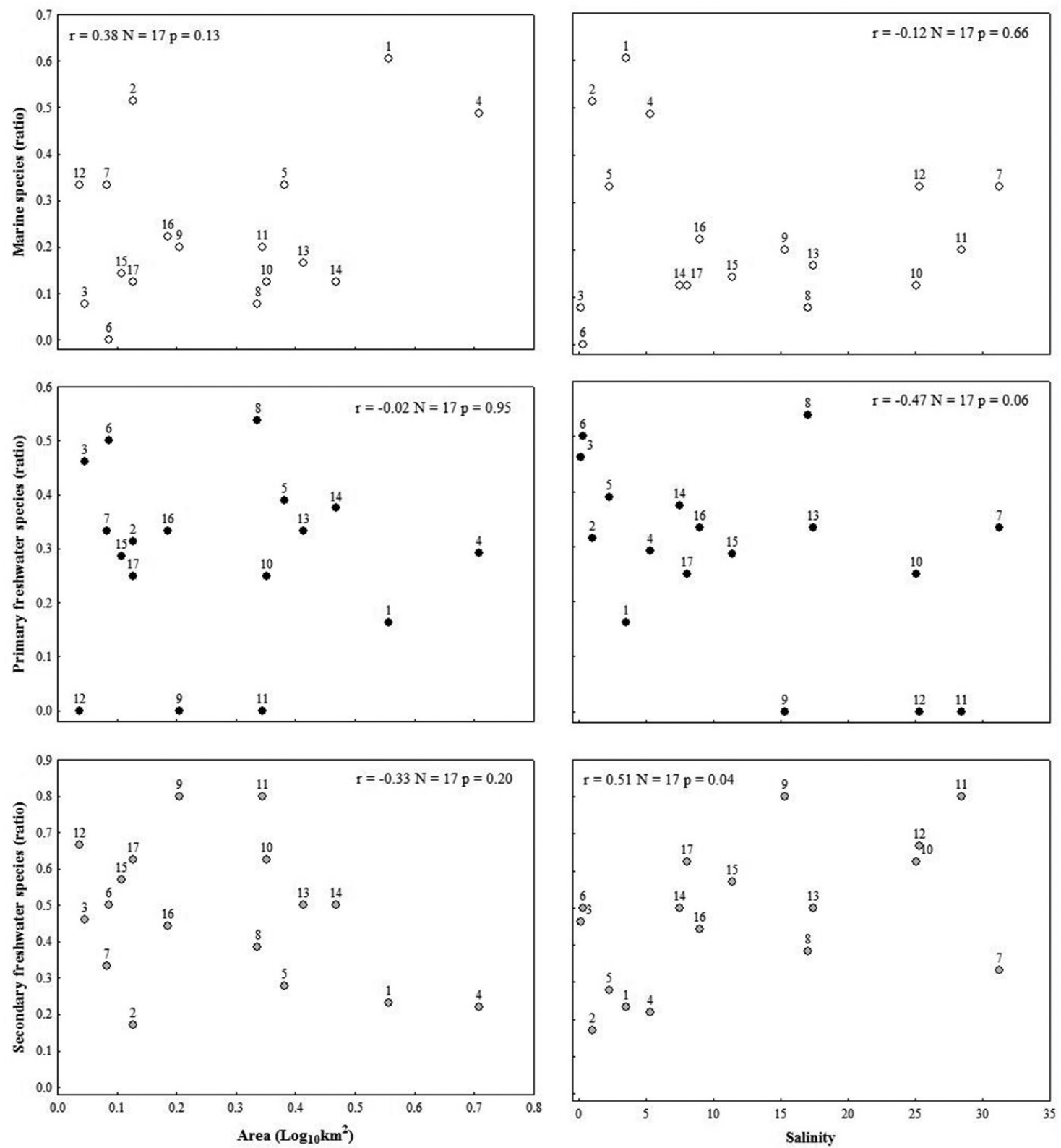

Figure 3. Relationships between the ratio of marine species (upper row), species of the Primary (middle row) and Secondary Divisions (lower row), and the area (left column) and salinity (right column) of each lagoon. Numbers 1-17 refer to lagoons depicted in Figure 1.

Park. One of them is the pacu-peva Metynnis maculatus, whose occurrence in the Park is herein reported for the first time. That species is originally restricted to the Amazon and Paraguay river basins (Jégu, 2003), but pacu-pevas have been introduced in the rio Paraíba do Sul basin for fishing purposes (e.g., Terra et al., 2010; Polaz et al., 2011). It is not clear if their occurrence in the Carapebus Lagoon results from a natural geographic expansion from the rio Paraíba do Sul basin to the lagoons of the Park. We suppose instead that $M$. maculatus was artificially introduced in the Carapebus Lagoon and possibly in other larger lagoons of the region. As $M$. maculatus is now frequently observed and collected in the Carapebus Lagoon, it seems that that population is well established. The occurrence of pacu-pevas in other lagoons of the Park and the possible effects of their introduction into these ecosystems should be monitored in future studies.

Another introduced species recorded in several lagoons of the Restinga de Jurubatiba National Park and the Imboassica Lagoon is the African tilapia, Tilapia rendalli. That species is frequently caught in moderate to high quantities, and seems to be 
well established in the Park. The guppy Poecilia reticulata, recorded in the Imboassica Lagoon only among the lagoons studied, is widely regarded as an easily adaptable exotic species. Their occurrence in the Imboassica Lagoon indicates that the species is likely to succeed in the lagoons of the Park in the case of one or more events of introduction. It is also possible that guppies are already inhabiting the less explored lagoons or pools inside the Park, especially those with moderate to higher levels of salinity. Another species that has been introduced in the northern Rio de Janeiro State and is actually thriving in some rivers, such as in the lower portion of the rio Macaé, is the North African catfish Clarias gariepinnus (e.g., Araújo, 2012). That species is extremely resilient, occurring in several different habitats, especially in lentic environments similar to those of the Jurubatiba National Park. Clarias gariepinnus is a generalist predator that can reach up to $150 \mathrm{~cm}$ TL (Teugels, 2003). The species is also able to naturally disperse through land between closely located water bodies or during flood events. The introduction of $C$. gariepinnus into the lagoons of the Restinga de Jurubatiba National Park would certainly represent a major impact into their fish communities.

The relatively high number of typically marine species recorded in the lagoons of the Restinga de Jurubatiba National Park and the Imboassica Lagoon clearly indicates that their fish fauna communities are largely influenced by the sea. Some Resident species of marine fishes, such as Atherinella brasiliensis and the species of Centropomus, Diapterus, Eucinostomus, and Mugil, are apparently spending their whole life cycles in lagoons where salinity levels are relatively high. However, other marine species regarded as Residents and Occasional enter the lagoons probably through a combination of two different processes, whose relative influences to the fish composition probably vary according to the orientation of the lagoons. In Orthogonal lagoons, we suspect that the intrusion of marine species is mostly related to events of sandbar breaching. Those events naturally occur in several lagoons of the region, and are artificially induced in the Imboassica Lagoon and, less frequently, in the Carapebus and Paulista lagoons. In Parallel lagoons, sandbar breaching is less frequent or practically inexistent in the recent geological history. However, marine species might be able to penetrate those lagoons during events of extremely high and strong tides, when sea waves are known to overcome the sandbars, carrying larvae and juveniles into the lagoons. The high frequency of occurrence of those events in the lagoons of the region probably explain why a correlation between levels of salinity and presence of marine fishes or of fishes of the Primary Division of Myers (1938) was not found. A combination of those events, sandbar breaching and intrusion of larvae and juveniles during extreme high and strong tides, is also probably correlated with the higher number of Occasional species found in Orthogonal lagoons. However, Orthogonal lagoons such as the Imboassica, Cabiúnas and Carapebus are also deeper and have a larger area. Those factors together might also contribute to the higher number of species recorded in them, even though a correlation between the area alone and species richness was not supported according to our results.

A higher similarity in terms of species composition among Parallel lagoons, when compared to Orthogonal ones, was also observed. This result might reflects the lower number of species recorded in the Parallel lagoons in comparison to the Orthogonal ones, which are more influenced by the sea in terms of species composition. Parallel lagoons are also geographically closer among themselves, but they are not connected through the Campos-Macaé channel. This artificial channel was constructed in the XIX century and connects some Orthogonal lagoons located between the rio Paraíba do Sul and the rio Macaé (Figure 1). However, other minor channels that connect the distal (opposite to the sea) portion of the Parallel lagoons might also help to explain why their fish communities seem to be more similar when compared to Orthogonal lagoons. Floods in strong rainy season, which are relatively common in the region, might also sporadically connect the Parallel lagoons, promoting a higher similarity among their fish communities.

\section{Identification key of Resident species recorded in the Imboassica Lagoon and in the Restinga de Jurubatiba National Park}

The identification key below includes 57 Resident species of fishes recorded in the Imboassica Lagoon and the Restinga de Jurubatiba National Park. The key was constructed based upon examination of vouchered specimens by the authors and information from the literature, including original descriptions, taxonomic revisions, and several taxonomic guides, such as Géry (1977), Figueiredo and Menezes (1978, 1980, 2000), Menezes and Figueiredo (1980, 1985), Dawson (1982), Whitehead (1985), Britski et al. (2007), 
Graça and Pavanelli (2007), and Baumgartner et al. (2012). As in all regional keys, we strongly recommend that this key be used with caution. Table 1 lists all species of fishes that have been so far recorded in the Imboassica Lagoon and the Restinga de Jurubatiba National Park, including 43 that were regarded as Occasional and, consequently, are not included in the key. The species composition of those lagoons is largely influenced by the sea, with the consequence that some yet unrecorded stenotopic or euryhaline marine species might be occasionally collected. Several species of marine/ coastal herrings and anchovies, for instance, are commonly found in the region (e.g., Whitehead, 1985; Whitehead et al., 1988), but only a fraction of those species have been collected in the lagoons. A single species of silverside, Atherinella brasiliensis (Atheriniformes: Atherinopsidae) was recorded in our study, but a morphologically similar species, $A$. blackburni, is reported from the northern Rio de Janeiro State (Mattox et al., 2008). Another species of silverside, Odontesthes argentinensis, was recorded only recently in the region (Di Dario et al., 2011). Those species have not yet been collected in the lagoons of the Restinga de Jurubatiba National Park or in the Imboassica Lagoon, but their occurrence in those water bodies should not be disregarded.

1a. Body asymmetric, both eyes on the same side of the body.

1b. Body bilaterally symmetrical, eyes on each side of the body. . .5

2a. Both eyes on the left side of the body; margin of preopercle exposed ... 3

$2 \mathrm{~b}$. Both eyes on the right side of the body; margin of preopercle covered by skin.

3a. Origin of the dorsal fin closer to the anterior nostril than to the posterior nostril; posterior end of upper jaw extending to the pupil of the ventral eye.

Citharichthys arenaceus

3b. Origin of dorsal fin equidistant between anterior and posterior nostrils, or close to posterior nostril; posterior end of upper jaw reaching the posterior border of the orbit of the ventral eye Citharichthys spilopterus

4a. Dorsal fin with 48-53 rays; body uniformly dark. Trinectes microphthalmus

4b. Dorsal fin with 55-60 rays; body with about 10 dark transverse bands from tip of snout to caudal-fin base

Trinectes paulistanus

5a. Body elongated, anguilliform, or knife- shaped; pelvic fins absent 5b. Body not elongated, different from the conditions above; pelvic fins present................ 10

6a. Pectoral fins absent; a single gill opening, located in the midline of the ventral portion of the head. Synbranchus aff. marmoratus

6b. Pectoral fins present; independent gill openings, laterally-placed in the head.... . .7

$7 \mathrm{a}$. Body covered by sequential rings of bony plates; anal fin absent or reduced, with less than 10 rays; dorsal and caudal fins present 8

7b. Body covered with scales; anal fin developed, with more than 100 rays; dorsal and caudal fins absent ... 9

8a. Anal fin absent; body covered by 13-14 bony plates; median ridge of the trunk rising approximately at the anus region, continuing to the posterior region of the body as the upper tail crest; brood pouch caudal............ Pseudophallus mindii

8b. Anal fin present, reduced; body covered by 16-19 bony plates; median ridge of the trunk continuous with the ventral caudal crest at the anus region; brood pouch abdominal Microphis lineatus

9a. Body cylindrical at the trunk region; mouth directed upwards, relatively wide, larger than or equal to the interorbital distance ..... Gymnotus aff. carapo

9b. Body laterally compressed at the trunk region; mouth terminal or directed downwards, relatively small, smaller than the interorbital distance............. Brachyhypopomus janeiroensis 10a. Spines absent on fins, fins formed only by soft rays.

10b. Spines present on fins, soft rays absent or present on fins

11a. Mouth protractile, terminal or directed upwards; upper jaw formed by premaxilla only. 12 11 b. Mouth not protractile, terminal or directed downwards; upper jaw formed by the maxilla and premaxilla.

12a. Anal fin with 12-13 rays; dorsal fin displaced posteriorly in relation to the middle portion of the body; branchiostegal and opercular membranes united; anal fin of males without copulatory organ (gonopodium) ...........Atlantirivulus jurubatibensis

12b. Anal fin with less than 10 rays; dorsal fin in the middle portion of the body; opercular and branchiostegal membranes separate; anal fin of adult males modified, forming a copulatory organ (gonopodium)

13a. Several lateral small dark blotches variously shaped, sometimes in the form of small dashes or 
forming a longitudinal stripe along the body; pelvic fins in the abdominal region; gonopodium formed by all anal-fin rays, forming a single tube, without distal appendages. .. Jenynsia multidentata 13b. Lateral blotches, when present, circular or forming vertical lines; pelvic fins in the thoracic region; gonopodium formed only by rays $3-5$, with small appendages at their distal tip 14

14a. Vertical dark lines conspicuously present at the sides of the body. Phalloptychus januarius

14b. Vertical dark lines at the sides of the body absent or extremely faint, round dark spots present or absent 15

15a. Round dark spot on the side of the body posterior to the dorsal fin ...... Phalloceros harpagos

15b. Round dark spot on the side of the body absent or, if present, anterior to the dorsal fin.... 16

16a. Color of males and females similar; males and females with a round dark spot on the side of the body anterior to the dorsal fin; scales without dark pigmentation around the edges, general body coloration not reticulate; adult males only slightly smaller than females...

Poecilia vivipara

16b. Pronounced sexual chromatic dimorphism; color variable, usually more conspicuous in males, round spots present or absent in males and absent in females; edge of scales with dark pigmentation, forming a faint reticulate pattern; males markedly smaller than adult females Poecilia reticulata

17a. Lateral line restricted to the cephalic region, absent on sides of body.

17b. Lateral line developed, reaching the tail region, or restricted to the anterior third of the body... 21

18a. Snout round and elongated, "pig-like"; mouth located on ventral portion of head; mouth relatively developed, articulation between upper and lower jaws posterior to vertical through the posterior margin of orbit; abdominal scutes absent, except for pelvic scute at the anterior region of pelvic fins.

18b. Snout short, relatively truncate; mouth terminal or slightly directed upwards; mouth relatively small, articulation between upper and lower jaws anterior to vertical through the anterior margin of orbit; abdominal scutes present, forming a pronounced ventral keel in the abdominal region

19a. Teeth highly reduced in size and approximately equal in terms of development in both jaws; body comparatively high, greatest height contained less than four times in Standard Length ... Anchovia clupeoides 19b. Teeth well developed in both jaws, caninelike, slightly more developed and spaced in the lower jaw; body relatively elongated, greatest height contained more than four times in Standard Length............ Lycengraulis grossidens 20a. Pelvic fin with 8 rays.............. Lile piquitinga 20b. Pelvic fin with 7 rays.... Platanichthys platana 21a. Body cylindrical; adipose fin absent; caudal fin rounded 22

21b. Body laterally compressed; adipose fin present; caudal fin forked

22a. Rounded black spot on the posterior portion of the opercle present; only conical teeth at the jaws, more developed caniniform teeth absent; maximum Standard Length not exceeding $25 \mathrm{~cm}$, specimens usually smaller than that

Hoplerythrinus unitaeniatus

22b. Rounded black spot on the posterior portion of the opercle absent; jaws with both conical and highly developed caniniform teeth, specially at the anterior margin of the jaws; maximum Standard Length about $50 \mathrm{~cm}$, large specimens relatively common. Hoplias malabaricus

23a. Teeth on jaws absent (edentulous jaws) Cyphocharax gilbert

$23 \mathrm{~b}$. Teeth on jaws present, variously developed.............................................. 24

24a. Body markedly high, slightly rounded, 1.1 to 1.3 times in Standard Length; abdomen keelshaped; numerous round black spots on the sides of the body Metynnis maculatus

$24 \mathrm{~b}$. Body relatively elongated, more than 2.0 times in Standard Length; abdomen not markedly pronounced, not keel-shaped; dark spots absent on sides of body, or only one or two humeral dark spots present

25a. Snout highly elongated; highly developed conical teeth on both jaws, arranged in a single series in the premaxilla ........... Oligosarcus hepsetus

25b. Snout short; teeth multicuspidate, comparatively reduced, arranged in two series in the premaxilla

26a. Lateral line complete, reaching the caudal fin Astyanax aff. bimaculatus

26b. Lateral line incomplete, not reaching the caudal fin, typically restricted to the anterior half of the body......................................27

27a. Two elongated dark humeral spots; dark spot on the sides of the caudal peduncle absent; fin-rays more developed in larger specimens, especially in 
the pelvic fin; several chevron-shaped marks serially aligned on the sides of the body, more distinct in preserved specimens ..... Hyphessobrycon bifasciatus $27 \mathrm{~b}$. A single spot in the humeral region; dark spot on the sides of the caudal peduncle present; fins not increasing markedly in size during development; chevron-shaped marks serially aligned on the sides of the body absent or highly inconspicuous ..... 28

28a. Dark pigmentation on the edge of the scales present, forming a reticulate pattern of body coloration; dark lateral stripe absent; humeral spot approximately rounded, without a ventral projection in the shape of a comma Hyphessobrycon reticulatus

28b. Dark pigmentation on the edge of the scales absent, body coloration not reticulate, relatively uniform; dark lateral stripe present; humeral spot rounded, with a ventral projection similar to a comma..... Hyphessobrycon luetkenii

29a. Scales absent, body naked or covered by bony plates 30

29b. Scales present, bony plates absent .35 30a. Body conspicuously covered by bony plates . 31

30b. Body totally naked, scales and bony plates absent. 32

31a. Coracoid bones at the ventral portion of the body, between the pectoral fins, exposed.....

\section{Hoplosternum littorale}

$31 \mathrm{~b}$. Coracoid bones at the ventral portion of the body, between the pectoral fins, not exposed, covered by a relatively thick skin Callichthys callichthys

32a. Adipose-fin base short, less than half the length of anal-fin base; body coloration dark overall, lighter on ventral portion; genital papilla of males supported by anterior rays of anal fin, forming an intromittent organ......... Trachelyopterus striatulus

32b. Adipose-fin base long, half or more the length of anal-fin base; body coloration gray or brownish; males without a dimorphic anal fin.

33a. Anterior and posterior nostrils close; a single developed globular tooth-plate on each side of the mouth roof; gill membranes joined to isthmus and forming a free fold over it........ Genidens genidens

33b. Anterior and posterior nostrils separated; tooth-plates at the mouth roof absent of different from the above; gill membranes not forming a free fold over the isthmus. . .34 34a. Maxillary barbel long, extending beyond the pelvic-fin origin. Rhamdia cf. quelen

34b. Maxillary barbel short, not reaching the pelvicfin origin Acentronichthys leptos 35a. Two dorsal fins, both including spines and rays. 36

35b. A single dorsal fin, formed by spines and rays. 48

36a. Pelvic fins with 1 spine, anterior to soft rays. .37

36b. Pelvic fins formed only by soft rays, spines absent.

37a. Lateral line restricted to the cephalic region, absent on sides of the body.... ...38

37b. Lateral line present on sides of the body .. 39

38a. Second dorsal fin and anal fin densely covered by scales Mugil curema

38b. Scales restricted to the anterior and basal portions of the second dorsal fin and anal fin ...... Mugil liza

39a. A lateral silver stripe extending from the base of the pectoral fin to the origin of the caudal fin; anal fin with 1 spine. Atherinella brasiliensis

39b. Lateral silver stripe absent; anal fin with 3 spines, the second spine more developed ......... 40

40a. Lower branch of the first gill arch with 10-12 gill rakers; 65-70 lateral-line scales

Centropomus parallelus

40b. Lower branch of the first gill arch with 7-8 gill rakers; 70-75 lateral-line scales

Centropomus undecimalis

41a. Length of second dorsal-fin base equal to or shorter than length of the caudal peduncle; pelvic fins separated. Eleotris pisonis

41b. Length of second dorsal-fin base longer than length of caudal peduncle; pelvic fins fused, forming a suction-cup-like structure 42

42a. Posterior margin of the gill chamber (covered by opercle) with dermal lobes.......Awaous tajasica $42 \mathrm{~b}$. Posterior margin of the gill chamber (covered by opercle) without dermal lobes.

43a. Upper 3-5 pectoral-fin rays filamentous and free of the pectoral-fin membrane. Bathygobius soporator

43b. Pectoral fin without free rays .44 44a. Snout short, its length shorter than eye diameter; opercle partially covered by scales Evorthodus lyricus 
44b. Snout long, its length equal to or longer than eye diameter; opercle scaleless.

45a. Body with more than 50 transverse rows of scales from pectoral-fin base to caudal-fin base ....

Gobionellus oceanicus

45b. Body with less than 50 transverse rows of scales from pectoral-fin base to caudal-fin base. .46 46a. Second dorsal fin with 11 soft-rays; anal fin with 12 soft-rays. Ctenogobius boleosoma 46b. Second dorsal fin with 12 soft-rays; anal fin with 13 soft-rays.

47a. Ventral portion of the lateral side of the head with 4 or 5 dark vertical bars; a roughly circular spot above the pectoral fin base

Gobionellus stigmaticus

$47 \mathrm{~b}$. Ventral portion of the lateral side of the head without dark vertical bars, but with a longitudinal dark stripe under the eye; circular spot above the pectoral fin base absent..... Ctenogobius shufeldti

48a. Lateral line interrupted in the middle of the body, divided into a lower (anterior) and an upper (posterior) branches

48b. Lateral line continuous along the sides of the body. 51

49a. A developed lobe in the upper branch of the first gill arch present; a dark stripe across the eye . Geophagus brasiliensis

49b. Lobe in the upper branch of the first gill arch absent; no dark stripe across the eye 50

50a. Scales covering the basal (proximal) portion of the dorsal and anal fin-rays; a slightly prognathous jaw; round dark spot on the posterior portion of the dorsal fin absent .....Australoheros cf. macaensis 50b. Dorsal and anal fins without scales; upper jaw protruding slightly in relation to lower jaw; round dark spot on the posterior portion of the dorsal fin present ..... Tilapia rendalli

51a. Preopercular margin smooth. .52

51b. Preopercular margin finely denticulate..... 55

52a. Anal fin with 2 spines Ulaema lefroyi

52b. Anal fin with 3 spines, the first one usually small.

53a. Lower branch of the first gill arch with 8 (rarely 7) gill rakers, excluding rudiments and the raker at the angle; second anal-fin spine equal to or greater than eye diameter; tip of the spinous dorsal fin with a conspicuous black spot, separated from the darkish fin base by a white band

Eucinostomus melanopterus 53b. Lower branch of the first gill arch with 6-7 gill rakers, excluding rudiments and the raker at the angle; second anal fin spine smaller than eye diameter; spinous dorsal fin with blackish tip, but without the white stripe separating it from the fin base .54

54a. A narrow band of scales on the region anterior to the premaxillary groove, at the anterodorsal portion of the head, resulting in a single median, roughly circular, naked (scaleless) area at the top of the snout. Eucinostomus gula

54b. Narrow band of scales on the region anterior to the premaxillary groove, at the anterodorsal portion of the head, absent, resulting in a totally naked area that extends from the premaxillary groove to the anterior tip of the snout.....Eucinostomus argenteus

55a. Dark longitudinal stripes on body sides present; second anal-fin spine longer than length of the analfin base. Eugerres brasilianus

55b. Dark longitudinal stripes on body sides absent; second anal-fin spine shorter than length of the anal-fin base .56

56a. Anal fin with 3 spines; lower branch of first gill arch with 10-15 gill rakers...Diapterus auratus 56b. Anal fin with 2 spines; lower branch of first gill arch with 15-18 gill rakers

Diapterus rhombeus

\section{Acknowledgments}

We thank all naturalists and ichthyologists since Charles Darwin that devoted their efforts towards understanding the fish fauna of the lagoons of the northern Rio de Janeiro State, including several generations of students of the Universidade Federal do Rio de Janeiro (UFRJ) that in the last decades assisted in field and laboratory activities. We are also thankful to the ICMBio staff at the Restinga de Jurubatiba National Park for general assistance and encouragement to develop this study. George M. T. Mattox (UFSCar) and an anonymous reviewer provided insightful comments to the manuscript. Collecting permissions (33278-1 and 16028-1) were granted from ICMBio/MMA. Fundação de Amparo à Pesquisa do Estado do Rio de Janeiro" (FAPERJ), and "Conselho Nacional de Desenvolvimento Científico e Tecnológico” (CNPq) to PELD Site5. ACP also received a Research Productivity Scholarship (CNPq). Scholarships were provided by the "Coordenação de Aperfeiçoamento de Pessoal de Nível Superior" (CAPES) to EMC and CAPES/ FAPERJ to MMP. 


\section{References}

AGUIARO, T. and CARAMASCHI, EP. 1995. Ichthyofauna composition of three coastal lagoons in the north of the State of Rio de Janeiro (Brazil). Arquivos de Biologia e Tecnologia, vol. 38, p. 11811189.

ALLEN, GR. 1989. Freshwater fishes of Australia. Neptune City: T.F.H. Publications. 240 p.

ARAÚJO, PC. 2012. A influência do gradiente ambiental do estuário do Rio Macaé, RJ, na composição da ictiofauna: uma abordagem das guildas ecológicas. Rio de Janeiro: Universidade Federal do Rio de Janeiro. 80 p. [Dissertação de Mestrado em Ciências Ambientais e Conservação].

BAUMGARTNER, G., PAVANELLI, CS., BAUMGARTNER, D., BIFI, AG., DEBONA, T. and FRANA, VA. 2012. Peixes do baixo Rio Iguaçu. Maringá: Eduem. 203 p.

BOVE, CP. and PAZ, J., 2009. Guia de campo das plantas aquáticas do Parque Nacional da Restinga de Jurubatiba, Rio de Janeiro, Brasil. Rio de Janeiro: Museu Nacional. 175 p. Série Livros 35.

BRITSKI, HA., DE SILIMON, KZ. and LOPES, BS. 2007. Peixes do Pantanal. Manual de Identificação. 2. ed. Brasília: Embrapa. 230 p.

CALIMAN, A., CARNEIRO, LS., SANTANGELO, JM., GUARIENTO, RD., PIRES, AFP., SUHETT, AL., QUESADO, LB., SCOFIELD, V., FONTE, ES., LOPES, PM., SANCHES, LF., AZEVEDO, FD., MARINHO, CC., BOZELLI, RL., ESTEVES, FA. and FARJALLA, VF. 2010. Temporal coherence among tropical coastal lagoons: a search for patterns and mechanisms. Brazilian Journal of Biology, vol. 70, no. 3, p. 803-814. http://dx.doi.org/10.1590/S151969842010000400011

CAMARA, EM. 2010. Gradientes ambientais e a ictiofauna litorânea de ecossistemas costeiros: os efeitos de aberturas da barra arenosa em duas lagoas do Sudeste brasileiro, RJ. Rio de Janeiro: Universidade Federal do Rio de Janeiro. 100 p. [Dissertação de Mestrado em Ecologia].

CARAMASCHI, EP., SÁNCHEZ-BOTERO, JI., HOLLANDA-CARVALHO, P., BRANDÃO, CAS., SOARES, CL., NOVAES, JLC. and ARAÚJO, RB., 2004. Peixes das lagoas costeiras de Macaé: Estudos de caso. In ROCHA, CFD., ESTEVES, FA. and SCARANO, FR., orgs. Pesquisas de longa duração na Restinga de Jurubatiba: ecologia, história natural e conservação. São Carlos: Rima Editora, PELD/ CNPq. p. 309-337.

DAWSON, CE. 1982. Subfamilies Doryrhamphinae and Syngnathinae. In DAWSON, CE. and VARI, RP., orgs. Fishes of the Western North Atlantic, part eight: family Syngnathidae. New Haven: Sears Foundation for Marine Research (Memoir I), Yale University. p. $4-172$.
DE MACEDO-SOARES, PHM., PETRY, AC., FARJALLA, VF. and CARAMASCHI, EP. 2010. Hydrological connectivity in coastal inland systems: lessons from a Neotropical fish metacommunity. Ecology of Freshwater Fish, vol. 19, p. 7-18. http:// dx.doi.org/10.1111/j.1600-0633.2009.00384.x

DI DARIO, F., PETRY, AC., MINCARONE, MM., PEREIRA, MMS. and SANTOS, RM. 2011. New records of coastal fishes in the northern Rio de Janeiro State, Brazil, with comments on the biogeography of the Southwestern Atlantic Ocean. Journal of Fish Biology, vol. 79, p. 546-555.

ESCHMEYER, WN. 2013. Genera, species, references. Available from: <http://research.calacademy.org/ research/ichthyology/catalog/fishcatmain.asp >. Access in: July 2013.

FIGUEIREDO, JL. and MENEZES, NA. 1978. Manual de peixes marinhos do Sudeste do Brasil, II. Teleostei (1). São Paulo: Museu de Zoologia da Universidade de São Paulo. 110 p.

FIGUEIREDO, JL. and MENEZES, NA. 1980. Manual de Peixes Marinhos do Sudeste do Brasil, III. Teleostei (2). São Paulo: Museu de Zoologia da Universidade de São Paulo. 90 p.

FIGUEIREDO, JL. and MENEZES, NA. 2000. Manual de peixes marinhos do Sudeste do Brasil, VI. Teleostei (5). São Paulo: Museu de Zoologia da Universidade de São Paulo. 116 p.

GÉRY, J. 1977. Characoids of the world. Neptune City: T.F.H. Publications. 672 p.

GRAÇA, WJ. and PAVANELLI, CS. 2007. Peixes da planicie de inundação do Alto rio Paraná e áreas adjacentes. Maringá: Eduem. 241 p.

HOLLANDA-CARVALHO, P., SÁNCHEZ-BOTERO, JI., PELLEGRINI-CARAMASCHI, E. and BOZELLI, RL. 2003. Temporal variation of fish community richness in coastal lagoons of the Restinga de Jurubatiba Park, Rio de Janeiro, Brazil. Acta Limnologica Brasiliensia, vol. 5, p. 31-40.

JÉGU, M. 2003. Subfamily Serrasalminae (Pacus and Piranhas). In REIS, RE., KULLANDER, SO. and FERRARIS JUNIOR, CJ., orgs. Check list of the freshwater fishes of South and Central America. Porto Alegre: Edipucrs. p. 182-196.

JENYNS, L. 1842. Part IV, fish. In DARWIN, C., org. The Zoology of the Voyage of H.M.S. Beagle, under the Command of Captain Fitzroy, during the years 1832 to 1836. London: Smith, Elder and Co. 172 p.

LUCINDA, PHF. 2003. Family Poeciliidae. In REIS, RE., KULLANDER, SO. and FERRARIS JUNIOR, CJ., orgs. Check list of the freshwater fishes of South and Central America. Porto Alegre: Edipucrs. p. 555-581.

MATTHEWS, WJ. 1998. Patterns in freshwater fish ecology. New York: Chapman \& Hall. 756 p.

MATTOX, GMT., GONDOLO, GF. and CUNNINGHAM, PTM. 2008. Atherinella 
blackburni (Schultz, 1949) at Itamambuca Beach, Ubatuba, SP: ecological characterization and distribution on the Brazilian coast (Teleostei: Atheriniformes: Atherinopsidae). Brazilian Journal of Biology, vol. 68, no 2, p. 307-313. http://dx.doi. org/10.1590/S1519-69842008000200011

McCUNE, B. and MEFFORD, MJ. 1999. PC-ORD: Multivariate analysis of ecological data. version 4. Oregon: MjM Software Design, Gleneden Beach.

MENEZES, NA. and FIGUEIREDO, JL. 1980. Manual de peixes marinhos do Sudeste do Brasil, IV. Teleostei (3). São Paulo: Museu de Zoologia da Universidade de São Paulo. 96 p.

MENEZES, NA. and FIGUEIREDO, JL. 1985. Manual de peixes marinhos do Sudeste do Brasil, V. Teleostei (4). Sáo Paulo: Museu de Zoologia da Universidade de São Paulo. 105 p.

MENEZES, NA., WEITZMAN, SH., OYAKAWA, OT., LIMA, FCT., CASTRO, RMC. and WEITZMAN, MJ. 2007. Peixes de água doce da Mata Atlântica. São Paulo: Museu de Zoologia da Universidade de São Paulo. 290 p.

MYERS, GL. 1938. Fresh-water fishes and West Indian zoogeography. Annual Report of the Board of Regents of the Smithsonian Institution, p. 339-364.

NICHOLS, JT. 1928. Fishes from the White Nile collected by the Taylor expedition of 1927: a discussion of the fresh-water fish faunae of Africa. American Museum Novitates, vol. 319, p. 1-7.

POLAZ, CNM., BATAUS, YSL., DESBIEZ, A. and REIS, ML. 2011. Plano de Ação Nacional para a conservação das espécies aquáticas ameaçadas de extinção da bacia do Rio Paraíba do Sul. Brasilia: ICMbio. 140 p. Série Espécies Ameaçadas, 16.

REIS, RE., KULLANDER, SO. and FERRARIS JUNIOR, CJ. 2003. Check list of the freshwater fishes of South and Central America. Porto Alegre: EdPUCRS. 729 p.

SAAD, AM., BEAUMORD, AC. and CARAMASCHI, EP. 2002. Effects of artificial canal openings on fish community structure of Imboassica Coastal Lagoon,
Rio de Janeiro, Brazil. Journal of Coastal Research, vol. 36, p. 634-639.

SÁNCHEZ-BOTERO, JI., GARCEZ, DS., CARAMASCHI, EP. and SAAD, AM. 2009. Indicators of influence of salinity in the resistance and resilience of fish community in a tropical coastal lagoon (Southeastern Brazil). Boletín de Investigaciones Marinas y Costeras, vol. 38, no. 1, p. 171-195.

StatSoft. 2007. STATISTICA (data analysis software system). version 8.0. Available from: <www.statsoft. com>.

TERRA, BF., SANTOS, ABI. and ARAÚJO, FG. 2010. Fish assemblage in a dammed tropical river: an analysis along the longitudinal and temporal gradients from river to reservoir. Neotropical Ichthyology, vol. 8, no. 3, p. 599-606.

TEUGELS, GG. 2003. Clariidae. In PAUGY, D., LÉVÊQUE, C. and TEUGELS, GG., orgs. The fresh and brackish water fishes of West Africa (Poissons d'eaux douces et saumâtres de l'Afrique de l'Ouest), Tome II. Collection Faune et Flore Tropicales 40. Paris: Institut de Recherche pour le Développement, Muséum National d'Histoire Naturelle, and Musée Royal de l'Afrique Centrale. p. 145-173.

WHITEHEAD, PJP. 1985. Clupeoid fishes of the world (suborder Clupeoidei). An annotated and illustrated catalogue of the herrings, sardines, pilchards, sprats, anchovies and wolfherrings. Part 1 - Chirocentridae, Clupeidae and Pristigasteridae. London: FAO. p. 1-304. FAO Fisheries Synopsis 7.

WHITEHEAD, PJP., NELSON, GJ. and WONGRATANA, T. 1988. Clupeoid fishes of the world (Suborder Clupeoidei). An annotated and illustrated catalogue of the herrings, sardines, pilchards, sprats, shads, anchovies and wolf-herrings. Part 2 - Engraulididae. London: FAO. p. 305-579. FAO Fisheries Synopsis, 7.

WILEY, EO. and JOHNSON, GD. 2010. A teleost classification based on monophyletic groups. In NELSON, JS., SCHULTZE, H-P. and WILSON, MVH., orgs. Origin and phylogenetic interrelationships of teleosts: honoring Gloria Arratia. München: Verlag Dr. Friedrich Pfeil. p. 123-182. 


\section{Appendix}

List of voucher specimens deposited in the Fish Collections of NPM and MNRJ collected in the Imboassica Lagoon and in the lagoons of the Restinga de Jurubatiba National Park. Number of specimens (in parentheses), name of lagoon, and date of collection, follow catalog number:

Achiridae: Achirus lineatus: NPM 235 (1), Imboassica, 25/05/2008. Trinectes microphthalmus: NPM 443 (2), Carapebus, 30/06/2008; NPM 453 (1), Imboassica, 25/05/2008; NPM 457 (1), Imboassica, 06/01/2010. Trinectes paulistanus: NPM 236 (2), Carapebus, 24/07/2008; NPM 471 (1), Carapebus, 24/05/2008. Anablepidae: Jenynsia multidentata: NPM 47 (28), Imboassica, 27/10/2008; NPM 71 (1), Garças, 02/11/2008; MNRJ 17510 (1), Preta; MNRJ 17516 (3), Preta; MNRJ 24223 (4), Pires, 05/08/2001. Ariidae: Genidens genidens: NPM 86 (3), Imboassica, 27/10/2008; MNRJ 24235 (1), Cabiúnas, 06/02/2002; MNRJ 26057 (1), Imboassica, 24/08/2000. Atherinopsidae: Atherinella brasiliensis: NPM 41 (10), Imboassica, 27/10/2008; NPM 44 (44), Imboassica, 27/10/2008; NPM 66 (74), Garças, 02/11/2008; NPM 87 (59), Imboassica, 27/10/2008; MNRJ 24230 (3), Paulista, 06/08/2001. Auchenipteridae: Trachelyopterus striatulus: MNRJ 24233 (1), Paulista, 16/03/2002; MNRJ 32422 (1), Cabiúnas, 08/12/2007; MNRJ 37614 (2), Cabiúnas, 18/08/2010. Belonidae: Strongylura marina: NPM 1 (1), Imboassica, 24/04/2008; NPM 62 (2), Imboassica, 27/10/2008. Callichthyidae: Hoplosternum littorale: NPM 835 (1), Cabiúnas, 28/09/2011. Carangidae: Caranx hippos: NPM 104 (3), Carapebus, 30/03/2008; NPM 448 (2), Carapebus, 19/02/2009. Caranx latus: NPM 74 (6), Imboassica, 27/10/2008; NPM 239 (1), Imboassica, 25/02/2008; NPM 451 (2), Imboassica, 29/06/2008. Oligoplites saurus: NPM 61 (1), Imboassica, 27/10/2008; NPM 456 (1), Imboassica, 25/05/2008. Trachinotus carolinus: NPM 469 (7), Carapebus, 19/02/2009. Trachinotus falcatus: NPM 468 (35), Carapebus, 19/02/2009. Centropomidae: Centropomus parallelus: NPM 63 (2), Imboassica, 27/10/2008; NPM 663 (38), Cabiúnas, 15/02/2011; NPM 827 (1), Cabiúnas, 28/09/2011; MNRJ 24237 (1), Cabiúnas, 07/08/2010; MNRJ 32423 (3), Cabiúnas, 08/12/2007. Centropomus undecimalis: NPM 225 (1), Imboassica, 27/06/2008; NPM 488 (3), Cabiúnas, 18/08/2010; MNRJ 37608 (2), Cabiúnas, 18/08/2010. Characidae: Astyanax bimaculatus: NPM 24 (417), Cabiúnas, 08/12/2007; NPM 498 (9), Cabiúnas, 18/08/2010; NPM 627 (3), Cabiúnas, 15/02/2011; NPM 826 (2), Cabiúnas, 28/09/2011; NPM 831 (1), Cabiúnas, 28/09/2011; MNRJ 24231 (3), Paulista, 16/03/2000; MNRJ 25989 (1), Cabiúnas, 15/10/2001; MNRJ 37612 (10), Cabiúnas, 18/08/2010; MNRJ 39352 (8), Cabiúnas, 28/09/2011. Hyphessobrycon bifasciatus: NPM 65 (248), Garças, 02/11/2008; NPM 510 (721), Comprida, 19/08/2010; NPM 534 (124), Cabiúnas, 18/08/2010; NPM 535 (11), Cabiúnas, 18/08/2010; NPM 568 (2), Cabiúnas, 15/02/2011; NPM 573 (1), Cabiúnas, 15/02/2011; NPM 585 (5), Cabiúnas, 14/02/2011; NPM 587 (2), Cabiúnas, 15/02/2011; NPM 594 (296), Comprida, 15/02/2011; NPM 608 (3), Cabiúnas, 15/02/2011; NPM 609 (5), Comprida, 16/02/2011; NPM 815 (14), Cabiúnas, 28/09/2011; NPM 820 (648), Comprida, 29/09/2011; NPM 824 (2), Cabiúnas, 28/09/2011; MNRJ 24225 (3), Carapebus, 07/08/2001; MNRJ 28460 (13), Cabiúnas, 28/04/2005; MNRJ 32419 (107), Cabiúnas, 08/12/2007; MNRJ 37602 (49), Cabiúnas, 18/08/2010; MNRJ 37615 (148), Comprida, 19/08/2010. Hyphessobrycon luetkenii: NPM 234 (6), Imboassica, 27/08/2008; NPM 499 (88), Cabiúnas, 18/08/2010; NPM 509 (53), Cabiúnas, 18/08/2010; NPM 570 (20), Cabiúnas, 15/02/2011; NPM 574 (26), Cabiúnas, 15/02/2011; NPM 582 (9), Cabiúnas, 15/02/2011; NPM 588 (32), Cabiúnas, 15/02/2011; NPM 606 (11), Cabiúnas, 14/02/2011; NPM 816 (31), Cabiúnas, 28/09/2011; NPM 841 (8), Cabiúnas, 28/09/2011; MNRJ 24238 (3), Cabiúnas, 06/02/2002; MNRJ 28463 (5), Cabiúnas, 28/04/2005; MNRJ 32418 (8), Cabiúnas, 08/12/2007. Hyphessobrycon reticulatus: NPM 500 (16), Comprida, 19/08/2010; NPM 572 (1), Comprida, 15/02/2011; NPM 819 (56), Comprida, 29/09/2011; MNRJ 25990 (1), poça da Piripiri, 15/10/2001. Metynnis maculatus: NPM 859 (4), Carapebus, 16/06/2011. Oligosarcus hepsetus: NPM 395 (3), Cabiúnas, 01/07/2008; NPM 489 (10), Cabiúnas, 18/08/2010; NPM 615 (2), Cabiúnas, 15/02/2011; NPM 626 (6), Cabiúnas, 15/02/2011; NPM 812 (2), Cabiúnas, 28/09/2011; NPM 830 (2), Cabiúnas, 28/09/2011; NPM 839 (4), Cabiúnas, 28/09/2011; MNRJ 11760 (1), Cabiúnas, 06/01/1982; MNRJ 24224 (3), Carapebus, 07/08/2001; MNRJ 25991 (1), Cabiúnas, 15/10/2001; MNRJ 32424 (31), Cabiúnas, 08/12/2007; MNRJ 37613 (6), Cabiúnas, 18/08/2010. Cichlidae: Australoheros macaensis: NPM 569, Cabiúnas, 15/02/2011; NPM 603, Cabiúnas, 15/02/2011; NPM 840, Cabiúnas, 28/09/2011; NPM 822, Cabiúnas, 28/09/2011; MNRJ 24226 (3), Carapebus, 07/08/2001; MNRJ 28459 (8), Cabiúnas, 28/04/2005. Geophagus brasiliensis: NPM 68 (19), Garças, 02/11/2008; NPM 485 (132), Comprida, 
19/08/2010; NPM 490 (41), Cabiúnas, 18/08/2010; NPM 583 (93), Comprida, 15/02/2011; NPM 619 (26), Cabiúnas, 14/02/2011; NPM 635 (1), Cabiúnas, 15/02/2011; NPM 813 (23), Cabiúnas, 28/09/2011; NPM 821 (71), Comprida, 29/09/2011; NPM 825 (2), Cabiúnas, 28/09/2011; NPM 833 (3), Cabiúnas, 28/09/2011; NPM 837 (1), Cabiúnas, 28/09/2011; MNRJ 17512 (4), Preta. MNRJ 24218 (3), Comprida, 19/07/2000; MNRJ 32413 (25), Cabiúnas, 08/12/2007; MNRJ 37607 (18), Cabiúnas, 18/08/2010; MNRJ 37617 (21), Comprida, 19/08/2010. Tilapia rendalli: NPM 43 (3), Imboassica, 27/10/2008; MNRJ 24228 (3), Carapebus, 28/02/2002. Clupeidae: Harengula cf. clupeola: NPM 268 (1), Imboassica, 01/12/2008. Lile piquitinga: NPM 35 (3), Imboassica, 21/08/2008; NPM 227 (13), Imboassica, 27/06/2008; NPM 251 (9), Imboassica, 27/04/2008; NPM 426 (4), Carapebus, 26/05/2008; NPM 427 (2), Carapebus, 26/02/2008; NPM 428 (2), Imboassica, 25/02/2008; NPM 429 (2), Carapebus, 26/02/2008; NPM 430 (2), Imboassica, 25/05/2008; NPM 431 (1), Imboassica, 22/07/2008; NPM 432 (1), Imboassica, 25/05/2008; NPM 433 (8), Imboassica, 22/07/2008; NPM 434 (1), Imboassica, 23/08/2008; NPM 435 (3), Imboassica, 23/08/2008; NPM 436 (1), Imboassica, 23/08/2008; NPM 437 (1), Imboassica, 28/09/2008; NPM 438 (1), Imboassica, 26/10/2008; NPM 439 (1), Imboassica, 01/12/2008; NPM 440 (1), Imboassica, 06/01/2009; NPM 441 (1), Imboassica, 18/02/2009; NPM 442 (7), Imboassica, 18/02/2009; MNRJ 37609 (11), Cabiúnas, 18/08/2010; MNRJ 39351 (29), Cabiúnas, 28/09/2011. Platanichthys platana: NPM 502 (28), Cabiúnas, 18/08/2010; NPM 586 (2), Cabiúnas, 14/02/2011; NPM 817 (107), Cabiúnas, 28/09/2011; MNRJ 24229 (1), Carapebus, 28/02/2002. Curimatidae: Cyphocharax gilbert: NPM 26 (22), Cabiúnas, 08/12/2007; NPM 479 (25), Cabiúnas, 18/08/2010; NPM 495 (28), Cabiúnas, 18/08/2010; NPM 507 (1), Cabiúnas, 18/08/2010; NPM 628 (48), Cabiúnas, 15/02/2011; NPM 636 (1), Cabiúnas, 15/02/2011; NPM 664 (65), Cabiúnas, 15/02/2011; NPM 807 (16), Cabiúnas, 28/09/2011; NPM 811 (41), Cabiúnas, 28/09/2011; NPM 828 (2), Cabiúnas, 28/09/2011; NPM 832 (3), Cabiúnas, 28/09/2011; MNRJ 24236 (1), Cabiúnas, 27/02/2002; MNRJ 32417 (26), Cabiúnas, 08/12/2007; MNRJ 37605 (1), Cabiúnas; MNRJ 37611 (19), Cabiúnas, 18/08/2010. Diodontidae: Chilomycterus spinosus: NPM 4 (1), Imboassica, 24/04/2008. Eleotridae: Eleotris pisonis: NPM 492 (1), Imboassica, 27/04/2008. Elopidae: Elops smithi: NPM 58 (1), Imboassica, 29/11/2008; NPM 59 (7), Imboassica, 27/10/2008; NPM 101 (8), Imboassica, 31/03/2008.

Engraulidae: Anchoa marinii: NPM 444 (2), Imboassica, 25/05/2008; NPM 450 (8), Carapebus, 24/05/2008. Anchovia clupeoides: NPM 64 (68), Imboassica, 27/10/2008; NPM 226 (1), Imboassica, 27/06/2008; NPM 233 (37), Carapebus, 27/09/2008; NPM 237 (3), Carapebus, 30/03/2008; NPM 245 (1), Imboassica, 28/09/2008; NPM 487 (1), Cabiúnas, 18/08/2010; NPM 549 (92), Carapebus, 27/09/2008; NPM 829 (5), Cabiúnas, 28/09/2011. Cetengraulis edentulus: NPM 97 (1), Carapebus, 26/02/2008. Lycengraulis grossidens: NPM 98 (7), Carapebus, 28/02/2008; NPM 461 (1), Carapebus, 27/09/2008; NPM 552 (4), Carapebus, 27/09/2008; NPM 838 (1), Cabiúnas, 28/09/2011. Erythrinidae: Hoplerythrinus unitaeniatus: NPM 823 (2), Comprida, 29/09/2011; MNRJ 17514 (3), Preta; MNRJ 24232 (3), Paulista, 16/03/2002; MNRJ 25992 (1), Comprida, 15/10/2001. Hoplias malabaricus: NPM 67 (3), Garças, 02/11/2008; NPM 483 (7), Comprida, 19/08/2010; NPM 548 (1), Cabiúnas, 18/08/2010; NPM 599 (6), Comprida, 15/02/2011; NPM 600 (7), Comprida, 16/02/2011; NPM 601 (14), Comprida, 16/02/2011; NPM 637 (1), Cabiúnas, 15/02/2011; NPM 806 (4), Comprida, 29/09/2011; NPM 808 (4), Cabiúnas, 28/09/2011; NPM 809 (4), Comprida, 29/09/2011; NPM 836 (2), Cabiúnas, 28/09/2011; MNRJ 17511 (5), Preta; MNRJ 24219 (3), Comprida, 19/07/2000; MNRJ 32416 (3), Cabiúnas, 08/12/2007; MNRJ 37604 (1), Cabiúnas, 18/08/2010. Gerreidae: Diapterus rhombeus: NPM 244 (1), Imboassica, 22/07/2008; NPM 446 (1), Imboassica, 25/02/2008. Eucinostomus argenteus: NPM 494 (6), Cabiúnas, 18/08/2010; MNRJ 37610 (7), Cabiúnas, 18/08/2010. Eugerres brasilianus: NPM 3 (1), Imboassica, 25/04/2008; NPM 103 (2), Carapebus, 30/03/2008; NPM 458 (2), Imboassica, 06/01/2010. Gobiidae: Awaous tajasica: NPM 470 (22), Carapebus, 17/02/2009; MNRJ 24234 (1), Cabiúnas, 27/08/2001. Bathygobius soporator: NPM 36 (2), Imboassica, 21/08/2008. Ctenogobius boleosoma: NPM 70 (1), Garças, 02/11/2008; NPM 240 (1), Imboassica, 25/02/2008; NPM 293 (7), Imboassica, 27/04/2008; NPM 460 (32), Carapebus, 19/02/2009. Ctenogobius shufeldti: NPM 527 (2), Imboassica, 29/04/2008. Evorthodus lyricus: NPM 267 (1), Imboassica, 23/08/2008. Gobionellus oceanicus: NPM 538 (1), Carapebus, 28/04/2008; MNRJ 32415 (1), Cabiúnas, 08/12/2007. Gymnotidae: Gymnotus aff. carapo: NPM 1857 (1), poça da Catingosa, 02/03/2012; NPM 1858 (1), poça da Catingosa, 28/11/2011. Haemulidae: Conodon nobilis: NPM 447 (1), Carapebus, 19/02/2009. Pomadasys crocro: NPM 105 (1), 
Carapebus, 28/02/2008; NPM 113 (1), Imboassica, 25/02/2008. Hemiramphidae: Hyporhamphus roberti: NPM 242 (2), Carapebus, 29/08/2008. Heptapteridae: Rhamdia cf. quelen: NPM 27 (1), Cabiúnas, 08/12/2007; NPM 481 (2), Cabiúnas, 18/08/2010; MNRJ 32425 (1), Cabiúnas, 08/12/2007; MNRJ 32426 (1), Cabiúnas, 08/12/2007. Hypopomidae: Brachyhypopomus janeiroensis: NPM 1573 (4), Comprida, 20/05/2011; NPM 1798 (11), Comprida, 05/09/2012; MNRJ 17509 (1), Preta. Monacanthidae: Stephanolepis hispidus: NPM 472 (1), Carapebus, 07/01/2009. Ophichthidae: Ophichthus cylindroideus: NPM 261 (1), Imboassica, 18/06/2009. Paralichthyidae: Citharichthys arenaceus: NPM 2 (1), Imboassica, 24/04/2008. Paralichthys orbignyanus: NPM 60 (1), Imboassica, 27/10/2008; NPM 302 (1), Imboassica, 01/09/2009. Poeciliidae: Phalloceros harpagos: NPM 539 (2), Comprida, 19/08/2010; NPM 576 (44), Comprida, 15/02/2011; NPM 818 (13), Comprida, 29/09/2011; MNRJ 24220 (3), Comprida, 17/03/2002; MNRJ 28462 (3), Cabiúnas, 28/04/2005. Phalloptychus januarius: NPM 638 (10), poça da Catingosa, 26/11/2010; NPM 639 (6), poça entre Catingosa e Visgueiro, 21/05/2010; NPM 640 (2), poça da Piripiri, 26/11/2010; NPM 641 (2), Garças, 27/11/2010; NPM 642 (4), poça da Piripiri, 19/05/2010; MNRJ 24222 (4), Pires, 05/08/2010. Poecilia vivipara: NPM 517 (6), Cabiúnas, 18/08/2010; NPM 524 (40), Cabiúnas, 18/08/2010; NPM 567 (2), Cabiúnas, 15/02/2011; NPM 571 (8), Cabiúnas, 15/02/2011; NPM 580 (2), Cabiúnas, 15/02/2011; NPM 604 (1), Cabiúnas, 15/02/2011; NPM 607 (133), Cabiúnas, 14/02/2011; NPM 814 (7), Cabiúnas, 28/09/2011; MNRJ 24221 (4), Pires, 05/08/2001; MNRJ 28461 (3), Cabiúnas, 28/04/2005; MNRJ 32420 (85), Cabiúnas, 08/12/2007. Polynemidae: Polydactylus oligodon: NPM 5 (1), Imboassica, 24/04/2008. Pomacentridae: Abudefduf saxatilis: NPM 269 (1), Imboassica, 27/04/2008. Rivulidae: Atlantirivulus jurubatibensis: NPM 553 (20), poça da Catingosa, 13/08/2010; NPM 1859 (10), poça da Catingosa, 02/03/2012. Sciaenidae: Micropogonias furnieri: NPM 69 (11), Garças, 02/11/2008. Stellifer brasiliensis: NPM 459 (2), Imboassica, 06/01/2010. Synbranchidae: Synbranchus aff. marmoratus: NPM 314 (1), Cabiúnas, 01/10/2009; NPM 748 (1), Comprida, 22/03/2012; NPM 1855 (1), Cabiúnas, 20/01/2012. Syngnathidae: Pseudophallus mindii: NPM 402 (1), Carapebus, 24/08/2008. Tetraodontidae: Sphoeroides pachygaster: NPM 449 (4), Carapebus, 19/02/2009. Sphoeroides testudineus: NPM 238 (2), Imboassica, 22/07/2008. 